\title{
Leukodepletion for patients undergoing heart valve surgery (Review)
}

\author{
Spencer S, Tang A, Khoshbin E
}

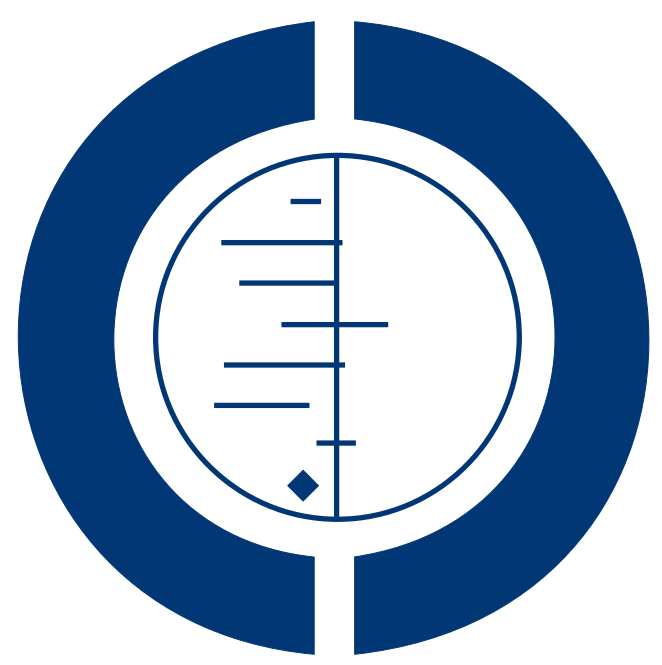

\section{THE COCHRANE COLLABORATION $^{\circledR}$}

This is a reprint of a Cochrane review, prepared and maintained by The Cochrane Collaboration and published in The Cochrane Library 2013, Issue 7

http://www.thecochranelibrary.com

\section{WILEY}


TABLE OF CONTENTS

HEADER . . . . . . . . . . . . . . . . . . . . . . . . . . . . . . . . . . . . 1

ABSTRACT . . . . . . . . . . . . . . . . . . . . . . . . . . . . . . . . . . . . . . . . . . . .

PLAIN LANGUAGE SUMMARY . . . . . . . . . . . . . . . . . . . . . . . . . . . . . . . . . . . 2

BACKGROUND . . . . . . . . . . . . . . . . . . . . . . . . . . . . . . . . . . . . . . . . .

OBJECTIVES . . . . . . . . . . . . . . . . . . . . . . . . . . . . . . . . . . . . . . . $4 \begin{gathered}4 \\ \text { O }\end{gathered}$

METHODS . . . . . . . . . . . . . . . . . . . . . . . . . . . . . . . . . . . . . . . . .

RESULTS . . . . . . . . . . . . . . . . . . . . . . . . . . . . . . . . . . . 6

Figure 1. . . . . . . . . . . . . . . . . . . . . . . . . . . . . . . . . . . . . 7

Figure 2. . . . . . . . . . . . . . . . . . . . . . . . . . . . . . . . . . . . . . . . . . . 9

DISCUSSION . . . . . . . . . . . . . . . . . . . . . . . . . . . . . . . . . . . . . . . . .

AUTHORS' CONCLUSIONS . . . . . . . . . . . . . . . . . . . . . . . . . . . . . . . . . . . . 11

ACKNOWLEDGEMENTS . . . . . . . . . . . . . . . . . . . . . . . . . . . . . . . . . . . 11

REFERENCES . . . . . . . . . . . . . . . . . . . . . . . . . . . . . . . . . . . . . . 12

CHARACTERISTICS OF STUDIES . . . . . . . . . . . . . . . . . . . . . . . . . . . . . . . . . . . . .

DATA AND ANALYSES . . . . . . . . . . . . . . . . . . . . . . . . . . . . . . . . . . . . . . . . . . 29

CONTRIBUTIONS OF AUTHORS . . . . . . . . . . . . . . . . . . . . . . . . . . . . . . . . . . . 29

DECLARATIONS OF INTEREST . . . . . . . . . . . . . . . . . . . . . . . . . . . . . . . . . . . . . . 29

SOURCES OF SUPPORT . . . . . . . . . . . . . . . . . . . . . . . . . . . . . . . . . . . . . . 29

DIFFERENCES BETWEEN PROTOCOL AND REVIEW . . . . . . . . . . . . . . . . . . . . . . . . . . . $\quad 29$

INDEX TERMS . . . . . . . . . . . . . . . . . . . . . . . . . . . . . . . . . . . . . . . . . . . . 30 


\title{
[Intervention Review]
}

\section{Leukodepletion for patients undergoing heart valve surgery}

\author{
Sally Spencer ${ }^{1}$, Augustine Tang ${ }^{2}$, Espeed Khoshbin ${ }^{3}$ \\ ${ }^{1}$ Faculty of Health and Medicine, Lancaster University, Lancaster, UK. ${ }^{2}$ Department of Cardiothoracic Surgery, Lancashire Cardiac \\ Centre, Victoria Hospital, Blackpool, UK. ${ }^{3}$ Cardiothoracic Surgery, University Hospital of South Manchester, Manchester, UK \\ Contact address: Sally Spencer, Faculty of Health and Medicine, Lancaster University, Bailrigg, Lancaster, Lancashire, LA1 4YD, UK. \\ s.spencer1@lancaster.ac.uk.
}

Editorial group: Cochrane Heart Group.

Publication status and date: New, published in Issue 7, 2013.

Review content assessed as up-to-date: 19 April 2013.

Citation: Spencer S, Tang A, Khoshbin E. Leukodepletion for patients undergoing heart valve surgery. Cochrane Database of Systematic Reviews 2013, Issue 7. Art. No.: CD009507. DOI: 10.1002/14651858.CD009507.pub2.

Copyright (C) 2013 The Cochrane Collaboration. Published by John Wiley \& Sons, Ltd.

\begin{abstract}
A B S T R A C T
Background

There is some evidence for the benefits of leukodepletion in patients undergoing coronary artery surgery. Its effectiveness in higher risk patients, such as those undergoing heart valve surgery, particularly in terms of overall clinical outcomes, is currently unclear.
\end{abstract}

Objectives

To assess the beneficial and harmful effects of leukodepletion on clinical, patient-reported and economic outcomes in patients undergoing heart valve surgery.

\section{Search methods}

We searched the Cochrane Central Register of Controlled Trials (CENTRAL) (2013, Issue 3 of 12) in The Cochrane Library, the NHS Economic Evaluations Database (1960 to April 2013), MEDLINE Ovid (1946 to April week 2 2013), EMBASE Ovid (1947 to Week 15 2013), CINAHL (1982 to April 2013) and Web of Science (1970 to 17 April 2013) on 19 April 2013. We also searched the World Health Organization (WHO) International Clinical Trials Registry Platform (ICTRP), the US National Institutes of Health (NIH) clinical trials database and the International Standard Randomised Controlled Trial Number Register (ISRCTN) in April 2013 for ongoing studies. No language or time period restrictions were applied. We examined the reference lists of all included randomised controlled trials and contacted authors of identified trials. We searched the 'grey' literature at OpenGrey and handsearched relevant conference proceedings.

\section{Selection criteria}

Randomised controlled trials comparing a leukocyte-depleting arterial line filter with a standard arterial line filter, on the arterial outflow of the heart-lung bypass circuit, in elective patients undergoing heart valve surgery.

\section{Data collection and analysis}

Data were collected on the study characteristics, three primary outcomes (1. post-operative in-hospital all-cause mortality within three months, 2. post-operative all-cause mortality excluding inpatient mortality $<30$ days, 3. length of stay in hospital, 4 . adverse events and serious adverse events) and seven secondary outcomes (1. tubular or glomerular kidney injury, 2. validated health-related quality of life scales, 3. validated renal injury scales, 4. use of continuous veno-venous haemo-filtration, 5. length of stay in intensive care, 6 . costs of care). Data were extracted by one author and verified by a second author. Insufficient data were available to perform a metaanalysis or sensitivity analysis.

Leukodepletion for patients undergoing heart valve surgery (Review)

Copyright $\odot 2013$ The Cochrane Collaboration. Published by John Wiley \& Sons, Ltd. 


\section{Main results}

Eight studies were eligible for inclusion in the review but data on prespecified review outcomes were available from only one, modestly powered (24 participants) study (Hurst 1997). There were no differences between a leuko-depleting versus standard filter in length of stay in the intensive care unit (ICU) (mean difference (MD) 0.80 days; $95 \%$ confidence interval (CI) -0.24 to 1.84 ) or length of hospital stay (MD 0.20 days; $95 \%$ CI -1.78 to 2.18 ).

\section{Authors' conclusions}

There are currently insufficient good quality trials with valve surgery patients to inform recommendations for changes in clinical practice. A future National Institute for Health Research (NIHR)-funded feasibility study (recruiting mid-year 2013) comparing leukodepletion with a standard arterial line filter in patients undergoing elective heart valve surgery (the ROLO trial) will be the largest study to date and will make a significant contribution to future updates of this review.

\section{PLAIN LANGUAGE SUMMARY}

\section{Leukodepletion for patients undergoing heart valve surgery}

Patients undergoing heart valve surgery are at a higher risk of developing complications after surgery, such as damage to the kidneys, compared with patients who undergo coronary artery surgery alone. The injury to organs is associated with an increased risk of death, longer stay in hospital and higher costs of care. A systemic inflammatory response is thought to be responsible for this effect. One possible mechanism for this response is activation of white blood cells (leucocytes) as they come into contact with the heart and lung bypass machine during surgery. In an attempt to avoid this inflammation response, special filters have been developed that capture the leucocytes while patients are on the bypass machine.

The authors of this review evaluated whether these filters were safe to use and effective in reducing the risk of death, length of stay in intensive care and hospital, impairment of kidney functioning, costs of care, and improving quality of life in patients undergoing heart valve surgery. We searched the literature and found eight studies, comprising at least 185 patients, that met our inclusion criteria for the review. However, only one study with 24 participants could provide data on any of our review outcomes. The study showed that length of stay in intensive care and length of stay in hospital were not different between patients who had surgery with the leukodepletion filter compared to a standard filter. None of the studies reported on death rates or five of the seven secondary outcomes that the review aimed to evaluate.

The authors concluded that there were not enough good quality trials in patients undergoing valve surgery to determine whether leukodepletion works. More good quality research studies with relevant outcome measures are required. A forthcoming study will help to clarify the findings in a future update of the review.

\section{B A C K G R O U N D}

\section{Description of the condition}

Diseases of the heart valves can dramatically worsen quality of life and cause premature death if left untreated. Although the underlying causes of heart valve disease vary considerably between developed and developing countries, the burden of disease in Western economies is substantial, partly due to an ageing population and the accompanying increase in degenerative valve diseases
(Soler-Soler 2000; Vahanian 2007). Prevalence of valvular heart disease in the general US population is estimated at $2.5 \%$, with age-related increases rising to $13 \%$ in people over 75 years (Nkomo 2006). In the period 2000 to 2010 , the proportion of valve surgeries in the United States rose from $16 \%$ to $22 \%$ of all cardiac surgeries (Iung 2011). Despite recent innovations, the gold standard treatment remains open heart surgery to repair or replace the damaged valves (Dunning 2011; Iung 2003). Positive outcomes of such surgery include increased life expectancy and improved quality of life (Brown 2009; Vahanian 2007). However, there are intrinsic risks associated with heart valve operations which cannot 
be avoided (Grayson 2003).

Patients undergoing heart valve surgery are at more than twice the risk of developing post-operative end organ injury, such as acute kidney injury (AKI), the most prevalent adverse event, compared with patients who undergo coronary artery surgery alone (Grayson 2003). The crude incidence of acute renal failure for isolated coronary artery bypass grafting, isolated valve operation, and a valve with coronary artery bypass grafting operation was $1.9 \%, 4.4 \%$, and $7.5 \%$, respectively $(\mathrm{P}<0.001)$ when estimated over a four-year period in the Liverpool Cardiothoracic Centre (Grayson 2003). Although the risk for acute kidney injury (AKI) is undoubtedly influenced by the presence of established patientrelated (increasing age, diabetes), cardiac (left ventricular ejection fraction $<40 \%$ ) and co-morbidity (pre-existing renal dysfunction) factors, valvular heart surgery per se is associated with an increased incidence of this complication due to the more prolonged heartlung bypass time and haemoglobinuria arising from haemolysis induced by extended cardiotomy suction. The international Kidney Disease: Improving Global Outcomes (KDIGO) guidelines define AKI when one of the following criteria is met: serum creatinine rises by $\geq 26 \mu \mathrm{mol} / \mathrm{L}$ within 48 hours or serum creatinine rises $\geq 1.5$ fold from the reference value (which is known or presumed to have occurred within one week) or urine output is < $0.5 \mathrm{ml} / \mathrm{kg} / \mathrm{hr}$ for $>6$ consecutive hours (KDIGO 2012). It is estimated that around $8 \%$ of patients undergoing heart surgery experience post-operative renal dysfunction and $1.5 \%$ require dialysis (Mangano 1998). Post-operative length of stay in the intensive care unit (ICU) may be twice as long for patients with renal dysfunction (five times longer for dialysis) and the mortality rate is also significantly higher at $27 \%$ for patients with post-operative renal dysfunction compared to $0.9 \%$ for those without (Mangano 1998). Even mild AKI is associated with a twofold increase in mortality rate, longer stay in ICU (x 1.6) and increased costs of care (x 1.6), with risk and costs escalating with severity of kidney injury (Dasta 2008). This same mechanism may lead to the failure of other organs (multi-organ dysfunction), which is a major cause of chronic ill-health and death (Thadhani 1996). Avoiding cardiac surgery associated AKI is therefore crucial due to the associated higher mortality rates, increased length of stay in ICU and elevated costs (Brown 2010; Dasta 2008).

\section{Description of the intervention}

A special device, called the leukodepletion (LG6) filter, has been developed that can successfully remove activated leukocytes (white blood cells) during the heart-lung bypass process which is mandatory for all heart valve surgery. These specially engineered filters combine a depth element with a screening component in order to trap activated leucocytes. Early studies demonstrated a reduction in inflammation and lung injury with the use of the filter during blood transfusions (Bando 1990; Bando 1991). Its effectiveness in removing the activated portion of leukocytes in circulating blood has been validated (Alexiou 2006; Gourlay 1992), though use of the filter is associated with an additional cost of approximately GBP 80 each. It was first used during heart and lung bypass surgery during the early 1990s (Palanzo 1993; Schueler 1992) and since then leukocyte filters have been used at different sites in the heartlung bypass circuit showing good performance and patient safety (Gu 1996; Gu 1999; Sawa 1994). Its effectiveness in ameliorating AKI, as defined by biomarkers, had been validated in low-risk coronary artery bypass patients (Tang 2002). The mode of action is to reduce the systemic inflammatory response (SIR) associated with use of the extra-corporeal circuit during heart-lung bypass. Peri-operative risk may be mediated by leucocyte activation, which may form the basis of SIR. The potential link between leucocyte activation and SIR is supported by evidence of a genetic basis for individual variation in the magnitude of SIR associated with cardiopulmonary bypass surgery (Jouan 2012). There is no evidence supporting a link between leucocyte activation and pre-existing co-morbidities in the cardiac surgical population.

\section{How the intervention might work}

A standard arterial line filter removes microemboli (gas, fat, aggregates) from blood passing through the cardiopulmonary bypass circuit. In addition, the leukodepletion filter has been proven to remove activated circulating leukocytes (Gourlay 1992; Gourlay 1992b; Gu 1999; Morris 2001; Thurlow 1996). When a patient's blood comes into contact with the artificial components of the heart and lung bypass circuit, the leucocytes become activated, which may lead to a SIR and the elevated risk of multi-organ dysfunction and death (Allen 1997; Butler 1993; Kirklin 1991; Westaby 1987). The role of activated leukocytes in the development of post-operative complications is well documented (Hunt 2007). Laboratory evidence for kidney protection (renoprotection) using the leukodepletion filter has been demonstrated with low-risk patients undergoing coronary artery surgery (Tang 2002). However, this study did not demonstrate clinical evidence of a reduction in kidney injury and the authors suggested that benefits may be more discernible in patients with moderate to high risk of developing kidney injury, for example, patients undergoing heart valve surgery. This cohort are at a higher risk of end-organ failure because they face additional challenges, such as increased time spent on the heart-lung machine and increased blood spillage and salvage. The sequelae of these additional challenges include an increase in leukocyte activation leading to a greater risk of morbidity and mortality. Reducing the number of activated leukocytes using a leukodepletion filter may reduce the risk of organ injury (Tang 2002). Leukodepletion may therefore reduce post-surgical mortality and length of stay, and improve long-term quality of life (Antunes 2004; Conlon 1999). To our knowledge there are no known side effects or harms associated with use of the leukodepletion filter compared to a standard arterial line filter. 


\section{Why it is important to do this review}

There is some evidence for the benefits of leukodepletion in patients undergoing coronary artery surgery (Bolcal 2007) but its effectiveness in higher-risk patients, such as those undergoing heart valve surgery, has not previously been reviewed. Evidence for the benefit of leukodepletion in terms of overall clinical outcomes in heart surgery is currently unclear (Efstathiou 2003; Fabbri 2001; Gott 2001; Sutton 2005). Although leukodepletion during cardiopulmonary bypass has contributed to improved heart and lung function, this has not translated into better overall clinical outcomes (Efstathiou 2003). This may be partly due to studies on lowrisk patients, who are not expected to have frequent complications (Tang 2002). The impact of heart surgery from the patient's perspective is an important consideration when evaluating the efficacy of an intervention. The subjective measurement of health-related quality of life (HRQoL) is an established outcome measure following cardiac surgery (Bennet 2002; Blumenthal 1994; Caine 1991; Papadopoulou 2009) and is able to predict post-surgical functional status (Falcoz 2003) and level of disability (Juergens 2010). In addition, post-operative HRQoL can be predicted by the severity of pre-operative heart failure and type of valve surgery (Baberg 2004; Falcoz 2003; Taillefer 2005). Pre-operative HRQoL scores have recently been confirmed as independent predictors of postoperative mortality and myocardial infarction, leading to a call for their inclusion in the standard set of assessments (Pedersen 2010). Evidence for the impact of leukodepletion on a patient's lifestyle and well-being has not previously been collated. A leukodepletion filter is relatively inexpensive compared to the cost of renal replacement therapy and prolonged intensive care, but few studies have evaluated cost savings. However, in a small US study Palanzo and colleagues reported potential savings in post-operative hospital costs of USD 2892 per patient (Palanzo 1993). Prevention of end-organ injury during valvular surgery could represent substantial cost savings (Mangano 1998) and it is therefore important to review the potential reduction in costs of care associated with use of the leukodepletion filter. It was the aim of this review to comprehensively evaluate the impact of leukodepletion on clini$\mathrm{cal}$, economic and health-related quality of life outcomes in patients undergoing heart valve surgery.

\section{Criteria for considering studies for this review}

\section{Types of studies}

Randomised controlled trials (RCTs)

\section{Types of participants}

\section{Included}

Adult ( $\geq 18$ years) patients requiring surgical intervention for heart valve disease, including single or multiple valves, first time or redo procedures. Trials considering concomitant procedures, such as coronary artery bypass graft, ascending aortic or root replacement, and ablation for atrial fibrillation, were considered for inclusion.

\section{Excluded}

Patients for whom the principal risk of peri-operative end-organ injury was related to factors other than heart valve surgery were excluded from the review, including patients with known preexisting renal disease, impaired left ventricular function $(\mathrm{EF}<$ $40 \%$ ), diabetes or requiring perioperative nephrotoxic medication, or deep hypothermic circulatory arrest.

\section{Types of interventions}

Studies that compared a leukocyte-depleting arterial line filter compared to a standard arterial line filter at any site in the heartlung bypass circuit.

\section{Types of outcome measures}

\section{Primary outcomes}

1. Post-operative in-hospital all-cause mortality (within three months)

2. Post-operative all-cause mortality excluding inpatient mortality $<30$ days

3. Length of stay in hospital

4. Adverse events: adverse events or serious adverse events (ICH-GCP 1997)

\section{METHODS}

Leukodepletion for patients undergoing heart valve surgery (Review)

Copyright $\odot 2013$ The Cochrane Collaboration. Published by John Wiley \& Sons, Ltd. 


\section{Secondary outcomes}

1. All forms of acute kidney injury (AKI), as defined by KDIGO 2012

2. Validated health-related quality of life scales (HRQoL)

3. Validated renal injury scale, e.g. Acute Kidney Injury

Network (AKIN) (Mehta 2007) or Risk, Injury, and Failure; and Loss, and End-stage kidney disease (RIFLE) (Bellomo 2004) criteria

4. Use of continuous veno-venous haemo-filtration $(\mathrm{CVVH})$

5. Length of stay in intensive care

6. Costs of care; cost-benefit, cost-effectiveness

\section{Search methods for identification of studies}

The search strategies are included in Appendix 1. The search criteria and overall strategy for identification of studies for this review is in accordance with the Cochrane Handbook for Systematic Reviews of Interventions (Lefebvre 2011).

\section{Electronic searches}

We searched the Cochrane Central Register of Controlled Trials (CENTRAL) (2013, Issue 3 of 12) in The Cochrane Library, the National Health Service (NHS) Economic Evaluations Database (1960 to April 2013), MEDLINE Ovid (1946 to April week 2 2013), EMBASE Ovid (1947 to Week 15 2013), CINAHL (1982 to April 2013) and Web of Science (1970 to 17 April 2013) on 19 April 2013.

We also searched the World Health Organization (WHO) International Clinical Trials Registry Platform (ICTRP) (http:// apps.who.int/trialsearch/), the US National Institutes of Health (NIH) clinical trials database (http://www.clinicaltrials.gov/) and the International Standard Randomised Controlled Trial Number Register (ISRCTN) (http://www.controlled-trials.com/isrctn/) in April 2013 for ongoing studies. No language or time period restrictions were applied.

The Cochrane sensitivity-maximising RCT filter was applied to MEDLINE and adaptations of it were applied to EMBASE and Web of Science (Lefebvre 2011).

We also conducted a wider search for reports of adverse events (Loke 2011) in a broad range of studies, for example quasi-experimental, cohort studies, etc., in MEDLINE Ovid (1946 to April week 3 2013) and EMBASE Ovid (1947 to 29 April 2013) on 30 April 2013 (Appendix 2).

\section{Searching other resources}

We examined the reference lists of all included RCTs and identified reviews for additional trials. We contacted authors of identified trials and authorities in the field in order to locate other published and unpublished studies. We searched the 'grey' literature at OpenGrey (http://www.opengrey.eu/) and handsearched the following conference proceedings from 2008 to April 2013: American Heart Association, European Society of Cardiology, International Conference on Heart \& Brain, International Meeting of Intensive Cardiac Care, Pan American Heart Failure Congress and South American Congress of Cardiology.

\section{Data collection and analysis}

\section{Selection of studies}

The titles and abstracts of all retrieved trials were independently assessed for relevance by two authors (SS and EK). Using the full text, each potentially eligible study was evaluated for inclusion in the review by the two authors. Disagreements about eligibility and inclusion were resolved following discussion with the third author (AT).

\section{Data extraction and management}

We used a data collection form based on the defined outcome measures. Data for the comparison of leukodepletion filter versus standard filter were extracted from included studies by one author (SS) and verified by a second author (EK). Where data were missing or further information was required we wrote to the study authors requesting the required information. Information on the design, participants, intervention, outcomes, methods, results and study withdrawals were recorded.

Two authors (SS and EK) evaluated the methodological quality of the studies. Disagreements and clarification on published data were resolved by consensus. Where no consensus was reached, the third author (AT) acted as mediator.

\section{Assessment of risk of bias in included studies}

We assessed the risk of bias for all included studies according to recommendations outlined in the Cochrane Handbook for Systematic Reviews of Interventions (Higgins 2011) for the following items.

1. Allocation sequence generation.

2. Concealment of allocation.

3. Blinding of participants and investigators.

4. Incomplete outcome data.

5. Selective outcome reporting.

Each potential source of bias was graded as high, low or unclear. Other sources of bias were noted.

\section{Measures of treatment effect}

Analyses were performed using Review Manager 5.2. For continuous data the treatment effect was estimated using a weighted mean difference (WMD) with a fixed-effect model. Dichotomous variables would have been compared using risk ratios (RR) with 
a fixed-effect model, but no data were available for analysis. If we had included trials with more than two arms and the variance of the difference between the leukodepletion filter and standard filter was not reported, we planned to calculate this from the variances of all the trial arms, but no such studies were included. If studies had only reported data for differences between treatment groups as opposed to mean effects for each group, we planned to analyse the data using the generic inverse variance (GIV) function with a fixed-effect model, but no such studies were included.

\section{Unit of analysis issues}

Where cross-over RCTs were identified for inclusion we planned to use data from only the first part of the study in order to minimise potential bias from carry-over effects, though no cross-over studies were identified for inclusion in the review. Where trials had more than two arms and the variance of the difference between the leukodepletion filter and standard filter was not reported, we planned to calculate this from the variances of all the trial arms. Where only data for differences between treatment groups were presented, as opposed to the mean effects for each group, we planned to analyse the data using the generic inverse variance (GIV) function with a fixed-effect model.

\section{Dealing with missing data}

We used an intention-to-treat approach and missing data were not imputed. Where applicable, all authors were contacted for missing data. If there had been enough trials, we had planned to use sensitivity analyses to determine the resistance of our results to the effects of missing data.

\section{Assessment of heterogeneity}

We planned to test for heterogeneity in Review Manager 5.1 using the $\mathrm{I}^{2}$ statistic, where an $\mathrm{I}^{2}$ greater than $40 \%$ is considered meaningful (Higgins 2011). If there had been enough trials we would have explored heterogeneity by checking data integrity and carrying out subgroup analyses.

\section{Assessment of reporting biases}

Had there been a sufficient number of studies, we planned to explore reporting biases and the effects of small studies using Egger's method (Egger 1997) to test for asymmetry in funnel plots.

\section{Data synthesis}

If there had been sufficient data, we planned to examine the combined effects of interventions by pooling data using meta-analysis. We planned to use fixed-effect models a priori, comparing the results with a random-effects model where substantial heterogeneity was indicated.

\section{Subgroup analysis and investigation of heterogeneity}

Where comparison group sample sizes permitted, we planned to conduct subgroup analyses for the following variables: heart disease severity (for example using the New York Heart Association classification), follow-up duration ( $\leq$ one month, > one month), age and sex.

\section{Sensitivity analysis}

Where substantial heterogeneity was present we planned to examine robustness of the results by comparing fixed-effect to randomeffects models. In addition, we planned to test reliability of the meta-analyses by repeating the tests with alternate decision pathways including risk of bias.

\section{RES U L T S}

\section{Description of studies}

See: Characteristics of included studies; Characteristics of excluded studies

\section{Results of the search}

A total of 4300 citations with abstracts were screened for relevance, of which 32 studies were identified as potentially eligible for inclusion. Full text papers were obtained for these studies and 19 were excluded from the review for the reasons listed in the table Characteristics of excluded studies. Five studies required clarification on type of surgery, nature of the control group or study design; we have written to the authors requesting further information. Details are listed in the table Characteristics of studies awaiting classification. Eight RCTs with 185 adult valve surgery patients undergoing cardiopulmonary bypass with either a leukodepletion or standard arterial line filter were eligible for inclusion in the review. One of these included patients undergoing either coronary artery bypass graft (CABG) or valve surgery, but did not state the number of patients in the subgroup undergoing valve surgery (Palanzo 1993). Details of the studies are shown in the table Characteristics of included studies and the study flow diagram is provided in Figure 1. Of the eight studies eligible for inclusion in the review only two included valve surgery patients alone (Hachida 1995; Hurst 1997). Two studies included CABG, congenital defect or valve surgery patients (Chen 2002; Leal-Noval 2005) and the remaining four studies included CABG or valve, or both, surgery patients (Chen 2004; Efstathiou 2003a; Palanzo 1993a; Soo 2010). We contacted all authors of the six mixed surgical population studies that included valve patients requesting information on this subgroup of patients alone, but no usable data 
were available. Of the two studies that included valve surgery patients alone, Hachida did not measure any of the outcomes specified in our review (Hachida 1995). Only Hurst (Hurst 1997) measured outcomes relevant to our review and details are reported below.

Figure I. Study flow diagram.

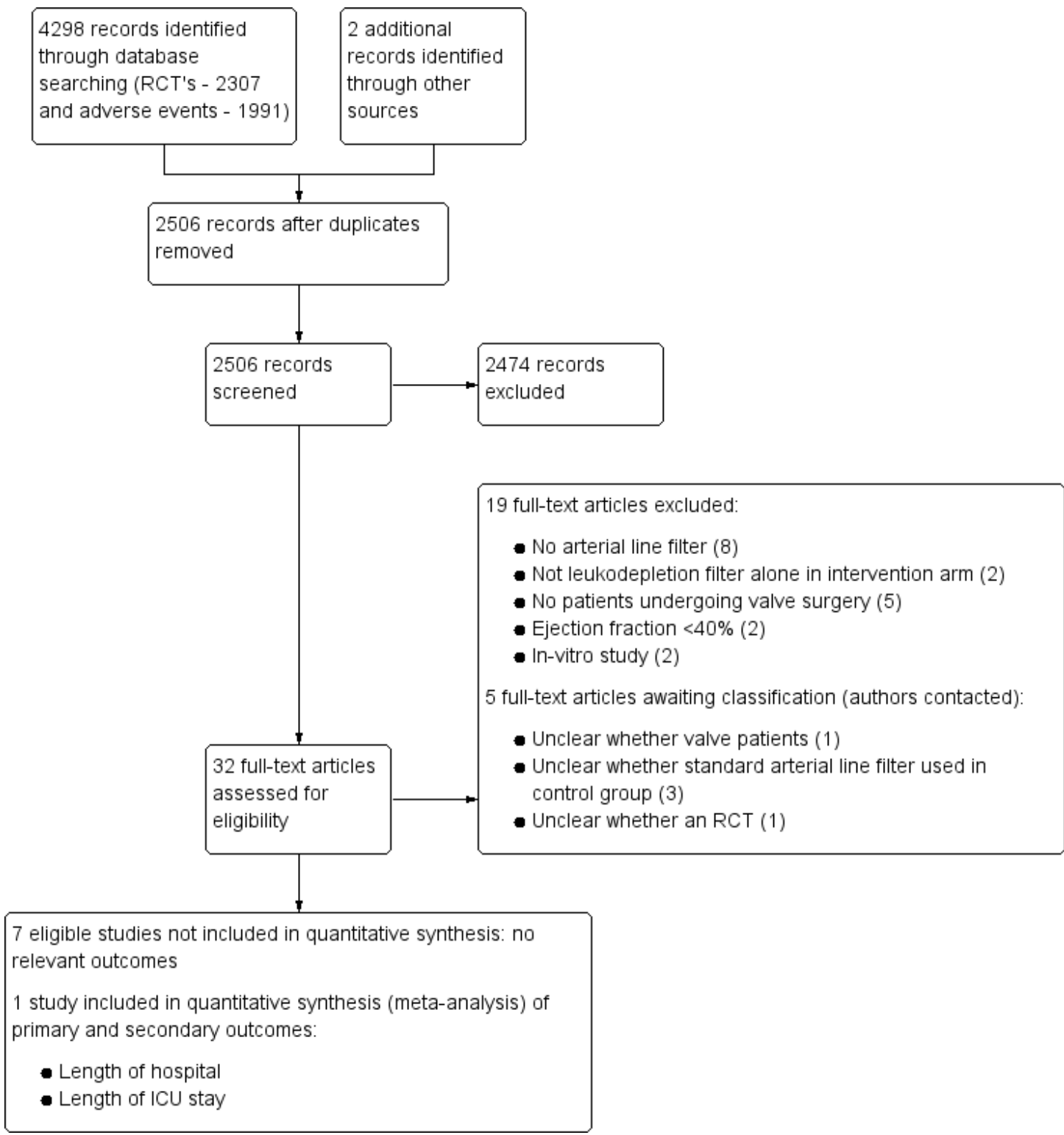




\section{Included studies}

\section{Study design}

Of the eight studies eligible for inclusion in the review, we were only able to obtain data on valve surgery patients for outcomes specified in the review from one study (Hurst 1997). This was a single centre RCT with investigators blinded to the intervention. Blinding of patients was not specifically reported but in our view it was highly unlikely that patients would know to which filter group they had been assigned without being specifically informed. Randomisation and allocation schedules were not reported in detail.

\section{Sample size}

The study included 24 participants, 11 randomised to a leukodepleting arterial line filter and 13 to a standard arterial line filter.

\section{Participants}

Patients were on average 62 years old ( $46 \%$ male) with a mean body mass index of 26.4. All patients electively received open heart valve surgery: six mitral valve, 12 aortic valve and six both. Nine patients had a left ventricular ejection fraction (LVEF) $<50 \%$ and we contacted the authors to determine whether any of these patients had an LVEF $<40 \%$, that is it would meet our exclusion criteria. Unfortunately these data were not available and we elected to include all of the study participants.

\section{Interventions}

The study compared a Pall LG6 arterial line leukodepletion filter with a Pall Autovent SP filter (standard arterial).

\section{Outcomes}

Mean cardiopulmonary bypass time was 160 minutes with a mean time of 113 minutes to cross-clamp release. Significantly more patients in the standard filter group reported cough prior to surgery compared to the leukodepletion group $(\mathrm{P}<0.05)$. There were no other significant differences between the groups prior to surgery. The study measured haemodynamics, white blood cell counts, platelet counts, cardiac index, blood gases, weight, chest x-rays, fluid balance, forced expiratory volume in one second (FEV1), forced vital capacity (FVC), echocardiography, fractional shortening, ejection fraction, wall motion abnormalities, atelectasis and myocardial infarctions. The only outcomes measured in the study that matched the protocol criteria were: total length of hospitalisation and length of ICU stay, therefore these were included in the review analyses.

\section{Excluded studies}

Nineteen studies did not meet the review inclusion criteria. Two were in vitro studies (Soo 2008; Soo 2009), eight studies did not use an arterial line leukodepletion filter (Bilgin 2002; Dell'Amore 2010; El-Tahan 2009; Gu 1999a; Pala 1995; Smit 1999; van de Watering 1996; Zhang 2010), six studies did not include valve surgery patients (Hamada 2001; Johnson 1995; Komai 1998; Lust 1996; Matheis 2001b; Scholz 2002), two studies used a compound intervention that included a leukodepletion filter amongst other intervention components (Gott 1998; Onorati 2011). One study met our review exclusion criteria with an ejection fraction $<40 \%$, reporting an average population ejection fraction below this criterion (Karaiskos 2004).

\section{Risk of bias in included studies}

Figure 2 shows the authors' (SS and EK) judgements on risk of bias of the included studies. Risk of bias in the one study that contributed data to the review was generally unclear, with the exception of personnel blinding, which was assessed as low risk of bias (Hurst 1997). 
Figure 2. Risk of bias summary: review authors' judgements about each risk of bias item for each included study.

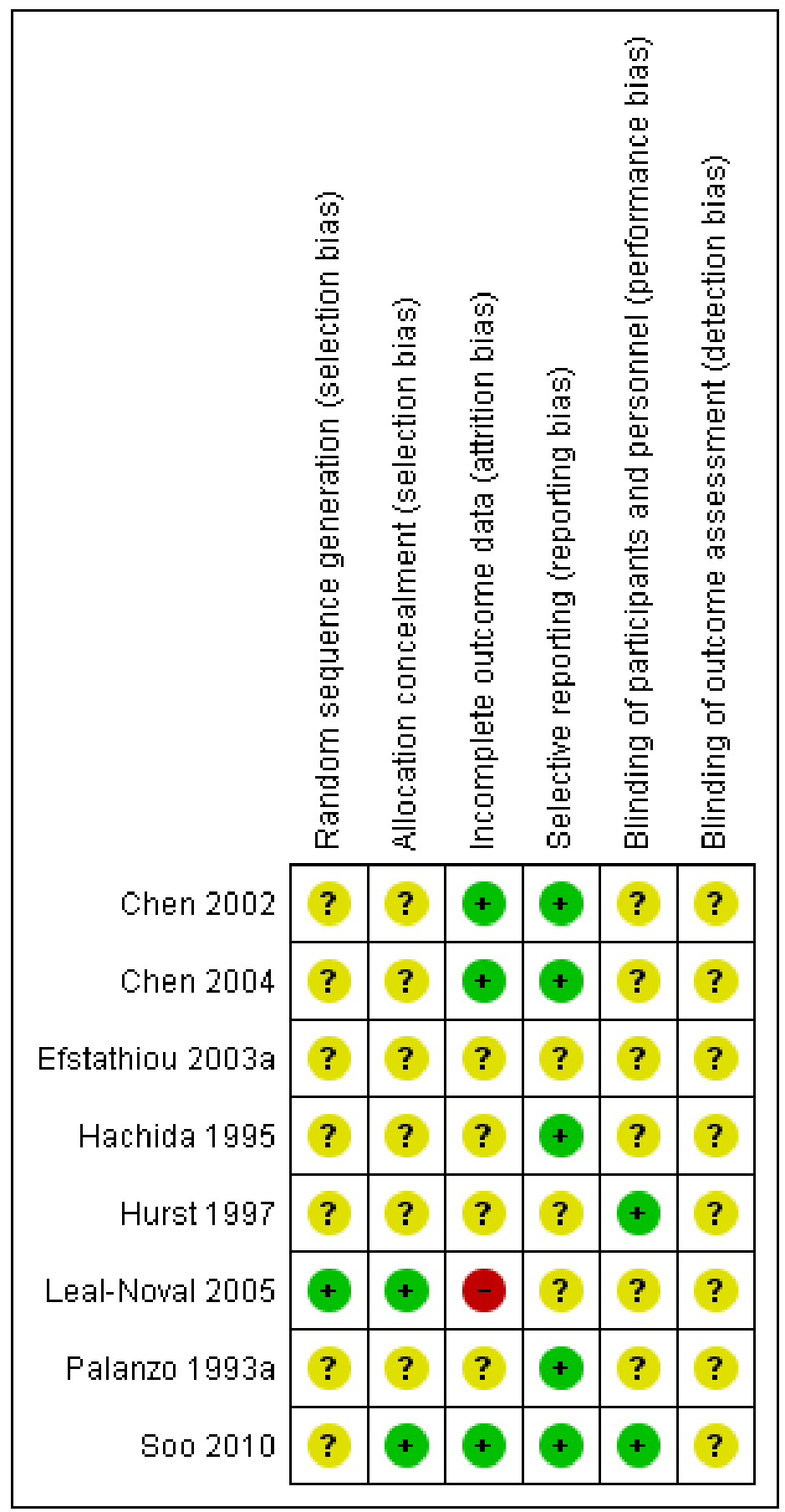

Leukodepletion for patients undergoing heart valve surgery (Review)

Copyright @ 2013 The Cochrane Collaboration. Published by John Wiley \& Sons, Ltd. 


\section{Allocation}

The randomisation sequence generation was clearly described in only one of the included studies (Leal-Noval 2005) and study allocation was clearly described in only two studies (Leal-Noval 2005; Soo 2010).

\section{Blinding}

Only two studies blinded study personnel (Hurst 1997; Soo 2010), with unclear blinding of personnel in the other studies. No studies specifically described blinding of participants. Blinding of outcome assessment to minimise detection bias was not reported in any of the eight studies.

\section{Incomplete outcome data}

Follow-up of all planned outcomes was clearly described in three of the studies (Chen 2002; Chen 2004; Soo 2010), unclear in four studies (Efstathiou 2003a; Hachida 1995; Hurst 1997; Palanzo 1993a), and one study had a high risk of attrition bias (Leal-Noval 2005).

\section{Selective reporting}

Reporting bias was unclear in three studies (Efstathiou 2003a; Hurst 1997; Leal-Noval 2005) but all planned outcomes were clearly reported in the other five studies.

\section{Effects of interventions}

\section{Primary outcomes}

Post-operative in-hospital all-cause mortality within three months of discharge and post-operative all-cause mortality excluding $<30$ day inpatient mortality were not measured in any of the included studies.

Data on length of hospital stay were available from only one study. No differences were indicated between the two groups (MD 0.20 days; $95 \%$ CI -1.78 to 2.18 ) (Analysis 1.1 ).

Adverse events were not reported in Hurst 1997. Of the other studies meeting our inclusion criteria, adverse events were measured in two studies (Efstathiou 2003a; Leal-Noval 2005) and serum creatinine ratio (a marker of renal function) was measured in one study (Soo 2010), but these data were not available solely for patients undergoing valve surgery.

\section{Secondary outcomes}

The only secondary outcome data available for analysis for valve surgery patients were for length of stay in ICU. There were no differences between the groups (MD 0.80 days; 95\% CI -0.24 to 1.84) (Analysis 1.2). This outcome was measured in four other studies (Efstathiou 2003a; Leal-Noval 2005; Palanzo 1993a; Soo 2010) but data were not available for valve surgery patients alone.

\section{DISCUSSION}

\section{Summary of main results}

Eight studies were eligible for inclusion in the review but data on prespecified review outcomes were only available from one modestly powered study (24 participants) (Hurst 1997). There were no differences in length of stay in ICU (MD 0.80 days; $95 \%$ CI -0.24 to 1.84 ) or length of hospital stay (MD 0.20 days; $95 \%$ CI -1.78 to 2.18$)$.

\section{Overall completeness and applicability of evidence}

Unfortunately the evidence base for this important question was largely incomplete due to the small number of studies with data relevant to our prespecified criteria and the limited data available from only one study. As the results are based on data from one small study the evidence has limited applicability.

\section{Quality of the evidence}

Eight studies with at least 185 valve surgery patients were eligible for inclusion in the review, but most had either low or modest power with the number of valve patients in six studies ranging from one to 28 (Chen 2002; Chen 2004; Efstathiou 2003a; Hachida 1995; Hurst 1997; Leal-Noval 2005). Another study did not report the number of valve surgery patients (Palanzo 1993a) and one study included 94 patients (Soo 2010). However, only one study with 24 participants contributed data to the analysis of two of the review outcomes. The risk of bias in the included studies was generally unclear, except for one study where risk of bias was generally low (Soo 2010). Reporting standards in the majority of studies were not consistent with CONSORT criteria for reporting of RCTs.

We were disappointed that data for valve surgery patients were not available from studies that had measured our predefined outcomes. We were also concerned that two of our primary and five 
of our secondary outcomes were not measured in any of the eight included studies. We will address this further in the section 'Implications for research'.

\section{Potential biases in the review process}

In order to reduce bias, a comprehensive and systematic search of the published and unpublished literature was conducted for potentially relevant studies. Where valve surgery patients were part of a mixed surgery population we contacted the authors for information on the valve surgery patients alone, but none was made available. The search results were examined by two independent authors in order to minimise bias in the selection process. We were unable to assess publication bias as too few trials contributed data to the review.

\section{Agreements and disagreements with other studies or reviews}

There are no other Cochrane reviews on leukodepletion for cardiac surgery. A number of reviews have examined the role of leukodepletion in cardiac surgery, largely recommending further high quality RCTs, but most have been in the context of coronary artery bypass graft (CABG) surgery (Asimakopoulos 2003; Boodram 2008; Matheis 2001a; Warren 2007a; Warren 2007b; Warren 2008; Whitaker 2001). However, a review by Loberg and colleagues considered that there was sufficient evidence to recommend that leukodepletion should not be used routinely in patients undergoing CABG surgery (Loberg 2011). Only one review included a subgroup analysis of valve surgery patients ( $\operatorname{Lim} 2007$ ), concluding that there was limited positive evidence of biochemical improvements but too few studies to draw firm conclusions with regard to clinical outcomes. This is consistent with the results of our review showing that the evidence base is limited by study composition, quality and size.

\section{AUTHORS' CONCLUSIONS}

\section{Implications for practice}

There are currently insufficient good quality trials that compare arterial line leukodepletion with standard arterial line filters in valve surgery patients to inform recommendations for changes in practice.

\section{Implications for research}

Future studies on arterial line leukodepletion in patients undergoing elective heart valve surgery should consider the following.

- The conduct of cardiopulmonary bypass ought to be standardized, where practicable, to eliminate potential confounding variables. This could be achieved for the majority of patients presenting for heart valve surgery.

- Inclusion of key clinical outcomes such as mortality, markers of renal impairment, health-related quality of life, adverse events and costs of care

- The potential renoprotective benefit of leukodepletion would logically be best assessed in those with preserved left ventricular (LV) function (ejection fraction $(\mathrm{EF})>40 \%$ ) in the first instance as poor LV function is an established independent predictor of post-operative renal dysfunction in this setting.

A future NIHR-funded feasibility study of leukodepletion versus a standard arterial line filter for patients undergoing elective heart valve surgery, led by Mr Augustine Tang, is due to begin in Spring 2013 (the ROLO trial). The study design conforms to international best practice for trial design and will measure most of the outcomes specified in this review. It aims to recruit 108 patients over 18 months. Once complete it will make a significant contribution to this review, being the largest study to date. The ROLO study is designed to inform parameterisation of a larger multicentre randomised controlled trial.

\section{ACKNOWLEDGEMENTS}

We would like to thank all study authors who responded to our request for further information. We also like to thank the Cochrane Heart Group for their constructive feedback and practical assistance during the review process. 


\section{R E F E R E N C E S}

\section{References to studies included in this review}

Chen 2002 \{published data only\}

Chen Y-F, Tsai W-C, Lin C-C, Lee C-S, Huang C-H, Pan P-C, et al.Leukocyte depletion attenuates expression of neutrophil adhesion molecules during cardiopulmonary bypass in human beings. The Journal of Thoracic and Cardiovascular Surgery 2002;123(2):218-24.

Chen 2004 \{published data only\}

Chen Y-F, Tsai W-C, Lin C-C, Tsai L-Y, Lee C-S, Huang $\mathrm{C}-\mathrm{H}$, et al.Effect of leukocyte depletion on endothelial cell activation and transendothelial migration of leukocytes during cardiopulmonary bypass. Annals of Thoracic Surgery 2004;78(2):634-42; discussion 42-3.

Efstathiou 2003a \{published data only\} Efstathiou A, Vlachveis M, Tsonis G, Asteri T, Psarakis A, Fessatidis IT. Does leukodepletion during elective cardiac surgery really influence the overall clinical outcome?. Journal of Cardiovascular Surgery 2003;44(2):197-204.

Hachida 1995 \{published data only\}

Hachida M, Hanayama N, Okamura T, Akasawa T, Maeda $\mathrm{T}$, Bonkohara $\mathrm{Y}$, et al.The role of leukocyte depletion in reducing injury to myocardium and lung during cardiopulmonary bypass. ASAIO Journal 1995;41(3): M291-4.

Hurst 1997 \{published data only\} Hurst T, Johnson D, Cujec B, Thomson D, Mycyk T, Burbridge B, et al.Depletion of activated neutrophils by a filter during cardiac valve surgery. Canadian Journal of Anaesthesia 1997;44(2):131-9.

Leal-Noval 2005 \{published data only\}

Leal-Noval SR, Amaya R, Herruzo A, Hernandez A, Ordonez A, Marin-Niebla A, et al.Effects of a leukocyte depleting arterial line filter on perioperative morbidity in patients undergoing cardiac surgery: a controlled randomized trial. Annals of Thoracic Surgery 2005;80(4): $1394-400$

Palanzo 1993a \{published data only\}

Palanzo DA, Manley NJ, Montesano RM, Yeisley GL, Gordon D. Clinical evaluation of the LeukoGuard (LG-6) arterial line filter for routine open-heart surgery. Perfusion 1993;8(6):489-96.

Soo 2010 \{published data only\}

Soo AW, Maher BM, Daly L, Wood AE, Watson WR. Preoperative neutrophil response as a predictive marker of clinical outcome following open heart surgery and the impact of leukocyte filtration. Interactive Cardiovascular and Thoracic Surgery 2010;11(5):604-11.

\section{References to studies excluded from this review}

Bilgin 2002 \{published data only\}

Bilgin YM, van de Watering LMG, Lorinser JE, Versteeg MIM, Eijsman L, van Oers MHJ, Brand A. Leukocytedepletion in cardiac surgery lowers postoperative infections but not multiple-organ-dysfunction-syndrome: results of a clinical study. Vox Sanguinis 2002;225:670.

Dell'Amore 2010 \{published data only\}

Dell'Amore A, Tripodi A, Cavallucci A, Guerrini F, Ronchi B, Zanoni S, et al.Efficacy of a new oxygenator-integrated fat and leukocyte removal device. Asian Cardiovascular \& Thoracic Annals 2010;18(6):546-50.

El-Tahan 2009 \{published data only\}

El-Tahan MR, Hamad RA, Ghoneimy YF, El-Shehawi MI, Shafi MA. Prospective, randomised placebo study of the effects of continuous ultra-filtration in hepatic patients after open-heart surgery. Anaesthesia 2009;64(8):927.

Gott 1998 \{published data only\}

Gott JP, Cooper WA, Schmidt FE, Brown WM 3rd, Wright CE, Merlino JD, et al.Modifying risk for extracorporeal circulation: trial of four antiinflammatory strategies. Annals of Thoracic Surgery 1998;66(3):747-53; discussion 53-4.

Gu 1999a \{published data only\}

Gu YJ, de Vries AJ, Vos P, Boonstra PW, van Oeveren W. Leukocyte depletion during cardiac operation: a new approach through the venous bypass circuit. Annals of Thoracic Surgery 1999;67(3):604-9.

Hamada 2001 \{published data only\} Hamada Y, Kawachi K, Nakata T, Kohtani T, Takano S, Tsunooka N. Antiinflammatory effect of heparin-coated circuits with leukocyte-depleting filters in coronary bypass surgery. Artificial Organs 2001;25(12):1004-8.

Johnson 1995 \{published data only\} Johnson D, Thomson D, Mycyk T, Burbridge B, Mayers I. Depletion of neutrophils by filter during aortocoronary bypass-surgery transiently improves postoperative cardiorespiratory status. Chest 1995;107(5):1253-9.

Karaiskos 2004 \{published data only\}

Karaiskos TE, Palatianos GM, Triantafillou CD, Kantidakis GH, Astras GM, Papadakis EG, et al.Clinical effectiveness of leukocyte filtration during cardiopulmonary bypass in patients with chronic obstructive pulmonary disease. Annals of Thoracic Surgery 2004;78(4):1339-44.

Komai 1998 \{published data only\} Komai H, Naito Y, Fujiwara K, Takagaki Y, Noguchi Y, Nishimura Y. The protective effect of a leucocyte removal filter on the lung in open-heart surgery for ventricular septal defect. Perfusion 1998;13(1):27-34.

Lust 1996 \{published data only\} Lust RM, Bode AP, Yang L, Hodges W, Chitwood WR. Inline leukocyte filtration during bypass - clinical results from a randomized prospective trial. ASAIO Journal 1996;42(5): M819-22.

Matheis 2001b \{published data only\} Matheis G, Scholz M, Simon A, Henrich D, WimmerGreinecker G, Moritz A. Timing of leukocyte filtration during cardiopulmonary bypass. Perfusion 2001;16 Suppl: 31-7. 
Onorati 2011 \{published data only\}

Onorati F, Santini F, Mariscalco G, Bertolini P, Sala A, Faggian G, et al.Leukocyte filtration ameliorates the inflammatory response in patients with mild to moderate lung dysfunction. Annals of Thoracic Surgery 2011;92(1): 111-21; discussion 21.

Pala 1995 \{published data only\}

Pala MG, Paolini G, Paroni R, De Veechi E, Gallorini C, Stefano PL, Di Credico G, Zuccari M, Galli L, et al.Myocardial protection with and without leukocyte depletion: a comparative study on the oxidative stress. European Journal of Cardiothoracic Surgery 1995;9(12): 701-6.

Scholz 2002 \{published data only\}

Scholz M, Simon A, Matheis G, Dzemali O, Henrich D, Kleine P, et al.Leukocyte filtration fails to limit functional neutrophil activity during cardiac surgery. Inflammation Research 2002;51(7):363-8.

Smit 1999 \{published data only\}

Smit JJ, de Vries AJ, Gu YJ, van Oeveren W. Efficiency and safety of leukocyte filtration during cardiopulmonary bypass for cardiac surgery. Transfusion Science 1999;20(3):151-65.

Soo 2008 \{published data only\}

Soo A, Maher B, Wood A, Watson W. Pre-operative neutrophil response as a predictive marker of clinical outcome following open-heart surgery and the impact of leukocyte filtration [abstract]. Irish Journal of Medical Science 2008;177 Suppl 7:S209. [DOI 10.1007/ s11845-008-0198-z]

Soo 2009 \{published data only\}

Soo A, Maher B, Watson W, Wood A. Preoperative individual neutrophil response as a predictive marker of clinical outcome following open heart surgery and the impact of leukocyte filtration. Interactive Cardiovascular and Thoracic Surgery 2009;8:S5.

van de Watering 1996 \{published data only\}

Van de Watering LMG, Houbiers JGA, Hermans J, Harvey MS, Bouter H, Boer F. Leukocyte depletion reduces postoperative mortality in patients undergoing cardiac surgery. Vox Sanguinis 1996;70 Suppl 2:37 (SY3D I06).

Zhang 2005 \{published data only\} Zhang GH, Hou FF, Wang WJ, Zhang X, Wu H, Liu ZQ, Tao HQ. The protective effects to the function of kidney and long by clearing of cytokines in patients with openheart surgery [Chinese]. National Medical Journal of China 2005;85(45):3194-8.

\section{References to studies awaiting assessment}

Allen 1994 \{published data only\}

Allen SM, Pagano D, Bonser RS. Pall leucocyte filter during cardiopulmonary bypass. Annals of Thoracic Surgery 1994; 58(5):1560. [DOI: 10.1016/0003-4975(94)91967-4]

de Vries 2003 \{published data only\}

de Vries AJ, Gu YJ, Post WJ, Vos P, Stokroos I, Lip H, et al.Leucocyte depletion during cardiac surgery: a comparison of different filtration strategies. Perfusion 2003;18(1):31-8.
Koskenkari 2006 \{published data only\}

Koskenkari JK, Rimpilainen J, Ohman H, Surcel H-M, Vainionpaa V, Biancari F, et al.Leukocyte filter enhances neutrophil activation during combined aortic valve and coronary artery bypass surgery. Heart Surgery Forum 2006;9 (4):E693-9.

\section{Ohto 2000 \{published data only\}}

Ohto T, Yamamoto F, Nakajima N. Evaluation of leukocytereducing arterial line filter (LG6) for postoperative lung function, using cardiopulmonary bypass. Japanese Journal of Thoracic and Cardiovascular Surgery 2000;48:295-300.

\section{Zhang 2010 \{published data only\}}

Zhang X, Zhou C, Zhuang J, Xiao X, Zheng S, Xiong W, et al.Effects of leukocyte depletion on cardiopulmonary protection and inflammation after valve surgery. International Journal of Artificial Organs 2010;33(11): 812-8.

\section{Additional references}

\section{Alexiou 2006}

Alexiou C, Sheppard S, Tang A, Rengarajan A, Smith D, Haw M, Gibbs R. Leukocytes-depleting filters preferentially remove activated leukocytes and reduce the expression of surface adhesion molecules during the simulated extracorporeal circulation of human blood. American Society for Artificial Internal Organs Journal 2006;52:438-44.

\section{Allen 1997}

Allen S. The role of leucocytes in the systemic inflammatory response and the potential impact of leucocyte depletion. Cardiovascular Engineering 1997;2:34-54.

Antunes 2004

Antunes PE, Prieto D, Ferrao de Oliveira J, Antunes MJ. Renal dysfunction after myocardial revascularization. European Journal of Cardiothoracic Surgery 2004;25: 597-604.

\section{Asimakopoulos 2003}

Asimakopoulos A, Gourlay T. A review of anti-inflammatory strategies in cardiac surgery. Perfusion 2003;18:7-12.

\section{Baberg 2004}

Baberg HT, Dirlich M, Laczkovics A, Grewe P, Bojara W, de Zeeuw J, et al.Determinants of health-related quality of life after aortic valve replacement in six-month survivors of intervention. Journal of Heart Valve Disease 2004;13(6): 914-20.

\section{Bando 1990}

Bando K, Pillai R, Cameron DE, Brawn JD, Winkelstein JA, Hutchins GM, et al.Leucocyte depletion ameliorates free radical mediated lung injury after cardiopulmonary bypass. Journal of Thoracic and Cardiovascular Surgery 1990; 99(5):873-7.

\section{Bando 1991}

Bando K, Schueler S, Cameron DE, DeValeria PA, Hatanaka M, Casale AS, et al.Twelve-hour cardiopulmonary preservation using donor core cooling, leucocyte depletion, and liposomal superoxide dismutase. Journal of Heart and Lung Transplantation 1991;10(2):304-9. 


\section{Bellomo 2004}

Bellomo R, Ronco C, Kellum JA, Mehta RL, Palevsky P. Acute renal failure - definition, outcome measures, animal models, fluid therapy and information technology needs: the Second International Consensus Conference of the Acute Dialysis Quality Initiative (ADQI) Group. Critical Care 2004;8(4):R204. [DOI: 10.1186/cc2872]

Bennet 2002

Bennet SJ, Oldridge NB, Eckert GJ, Embree JL, Browning $S$, Hou N, et al.Discriminant properties of commonly used quality of life measures in heart failure. Quality of Life Research 2002;11(4):349-59.

\section{Blumenthal 1994}

Blumenthal JA, Mank DB. Quality of life and recovery after cardiac surgery. Psychosomatic Medicine 1994;56(3):213-5.

Bolcal 2007

Bolcal C, Akay HT, Bingol H, Doganci S, Yildirim V, Yenicesu M, et al.Leukodepletion improves renal function in patients with renal dysfunction undergoing on-pump coronary bypass surgery:a prospective randomised study. The Thoracic and Cardiovascular Surgeon 2007;55(2):89-93.

\section{Boodram 2008}

Boodram S, Evans E. Use of leucocyte-depleting filters during cardiac surgery with cardiopulmonary bypass: A review. Journal of the American Society of Extra-Corporeal Technology 2008;40:27-42.

\section{Brown 2009}

Brown JM, O'Brien SM, Wu C, Sikora JH, Griffith BP, Gammie JS. Isolated aortic valve replacement in North America comprising 108,687 patients in 10 years: changes in risks, valve types, and outcomes in the Society of Thoracic Surgeons National Database. Journal of Thoracic and Cardiovascular Surgery 2009;137:82-90.

\section{Brown 2010}

Brown JR, Kramer RS, Coca SG, Parikh CR. Duration of acute kidney injury impacts long-term survival after cardiac surgery. Annals of Thoracic Surgery 2010;90(4):1142-8.

Butler 1993

Butler J, Rocker GM, Westaby S. Inflammatory response to cardiopulmonary bypass. Annals of Thoracic Surgery 1993; 55:552-98

Caine 1991

Caine N, Harrison SC, Sharples LD, Wallwork J. Prospective study of quality of quality of life before and after coronary artery bypass grafting. BMJ 1991;302(6775): $511-6$.

\section{Conlon 1999}

Conlon PJ, Stafford-Smith M, White WD, Newman MF, King S, Winn MP, Landolfo K. Acute renal failure following cardiac surgery. Nephrology, Dialysis, Transplantation 1999; 14:1158-62.

\section{Dasta 2008}

Dasta JF, Kane-Gill SL, Durtschi AJ, Pathak DS, Kellum JA. Costs and outcomes of acute kidney injury (AKI) following cardiac surgery. Nephrology, Dialysis, Transplantation 2008; 23(6):1970-4.

\section{Dunning 2011}

Dunning J, Gao H, Chambers J, Moat N, Murphy G, Pagano D, et al.Aortic valve surgery: marked increases in volume and significant decreases in mechanical valve use an analysis of 41,227 patients over 5 years from the Society for Cardiothoracic Surgery in Great Britain and Ireland National database. Journal of Thoracic and Cardiovascular Surgery 2011;142:776-82.

Efstathiou 2003

Efstathiou A, Vlachveis M, Tsonis G, Asteri T, Psarakis A, Fessatidis IT. Does leukodepletion during elective cardiac surgery really influence the overall clinical outcome?. Journal of Cardiovascular Surgery 2003;44(2):197-204.

\section{Egger 1997}

Egger M, Davey Smith G, Schneider M, Minder C. Bias in meta-analysis detected by a simple, graphical test. $B M J$ 1997;315((7109)):629-34.

Fabbri 2001

Fabbri A, Manfredi J, Piccin C, Soffiati G, Carta MR, Gasparotto E, Nardon G. Systemic leucocyte filtration during cardiopulmonary bypass. Perfusion 2001;16(1): $11-8$.

\section{Falcoz 2003}

Falcoz PE, Chocron S, Stoica L, Kaili D, Puyraveau M, Mercier M, Etievent JP. Open heart surgery: one-year selfassessment of quality of life and functional outcome. Annals of Thoracic Surgery 2003;76(5):1598-604.

\section{Gott 2001}

Gott JP. Leucodepletion and aprotinin improve clinical outcome after extracorporeal circulation. Perfusion 2001; S16:5-9.

\section{Gourlay 1992}

Gourlay T, Fleming J, Taylor KM. Laboratory evaluation of the Pall LG6 leukocyte depleting arterial line filter. Perfusion 1992;7:131-40.

\section{Gourlay 1992b}

Gourlay T, Fleming J, Taylor KM. The effects of pulsatile flow on the leukocyte depleting qualities of the Pall LG6 leukocyte depleting arterial line filter: a laboratory investigation. Perfusion 1992;7(3):227-32.

Grayson 2003 Grayson AD, Khater M, Jackson M, Fox MA. Valvular heart operation is an independent risk factor for acute renal failure. Annals of Thoracic Surgery 2003;75(6):1829-35.

\section{Gu 1996}

Gu YJ, de Vries AJ, Boonstra PW, van Oeveren W. Leucocyte depletion results in improved lung function and reduced inflammatory response after cardiac surgery. Journal of Thoracic and Cardiovascular Surgery 1996;112(2): 494-500.

Gu 1999

Gu YJ, de Vries AJ, Vos P, Boonstra PW, van Oeveren W. Leucocyte depletion during cardiac operation: a new approach through the venous bypass circuit. Annals of Thoracic Surgery 1999;67(3):604-9. 
Higgins 2011

Higgins JPT, Green S (editors). Cochrane Handbook for Systematic Reviews of Interventions Version 5.1.0 [updated March 2011]. The Cochrane Collaboration, 2011. Available from www.cochrane-handbook.org.

Hunt 2007

Hunt IJ, Day JRS. Cardiac surgery and inflammation. Current Cardiac Reviews 2007;3(1):91-8.

\section{ICH-GCP 1997}

International Conference on Harmonisation Expert Working Group. International conference on harmonisation of technical requirements for registration of pharmaceuticals for human use. ICH harmonised tripartite guideline. Guideline for good clinical practice1997 CFR \& ICH Guidelines. USA: Barnett International/PAREXEL, 1997; Vol. 1 .

Iung 2003

Iung B, Baron G, Butchart EG, Delahaye F, Gohlke-Barwolf C, Levang OW, et al.A prospective survey of patients with valvular heart disease in Europe: The Euro Heart Survey on Valvular Heart Disease. European Heart Journal 2003;24 (13):1231-43.

Iung 2011

Iung B, Vahanian A. Epidemiology of valvular heart disease in the adult. Nature Reviews Cardiology 2011;8:162-72.

Jouan 2012

Jouan J, Golmard L, Benhamouda N, Durrleman N, Gomard J-L, Ceccaldi R, et al.Gene polymorphisms and cytokine plasma levels as predictive factors of complications after cardiopulmonary bypass. Journal of Cardiothoracic and Cardiovascular Surgery 2012;144(2):467-73.

\section{Juergens 2010}

Juergens MC, Seekatz B, Moosdorf RG, Petrie KJ, Rief W. Illness beliefs before cardiac surgery predict disability, quality of life and depression 3 months later. Journal of Psychosomatic Research 2010;68(6):553-60.

\section{KDIGO 2012}

Kidney Disease: Improving Global Outcomes (KDIGO) Acute Kidney Injury Work Group. KDIGO Clinical Practice Guideline for Acute Kidney Injury. Kidney International 2012;2 Suppl:1-138.

\section{Kirklin 1991}

Kirklin JK. Prospects for understanding and eliminating the deleterious effects of cardiopulmonary bypass. Annals of Thoracic Surgery 1991;51:529-31.

Lefebvre 2011

Lefebvre C, Manheimer E, Glanville J. Chapter 6: Searching for studies. In: Higgins JPT, Green S editor(s). Cochrane Handbook for Systematic Reviews of Interventions Version 5.1.0 (updated March 2011). The Cochrane Collaboration, 2011.

Lim 2007

Lim HK, Anderson J, Leong JY, Pepe S, Salomonsen RF, Rosenfeldt FL. What is the role of leucocyte depletion in cardiac surgery. Heart, Lung and Circulation 2007;16: $243-53$.
Loberg 2011

Loberg AG, Stallard J, Dunning J, Dark J. Can leucocyte depletion reduce reperfusion injury following cardiopulmonary bypass?. Interactive Cardiovascular and Thoracic Surgery 2011;12:232-7.

Loke 2011

Loke YK, Price D, Herxheimer A. Chapter 14: Adverse effects. In: Higgins JPT, Green S editor(s). Cochrane Handbook for Systematic Reviews of Interventions Version 5.1.0 (updated March 2011). The Cochrane Collaboration, 2011. Available from www.cochrane-handbook.org.

\section{Mangano 1998}

Mangano CM, Diamondstone LS, Ramsay JG, Aggarwal A, Herskowitz A, Mangano DT. Renal dysfunction after myocardial revascularization: risk factors, adverse outcomes, and hospital resource utilization. The Multicenter Study of Perioperative Ischemia Research Group. Annals of Internal Medicine 1998;128:194-203.

\section{Matheis 2001a}

Matheis G, Scholz M, Simon A, Dzemali O, Moritz A. Leucocyte filtration in cardiac surgery: a review. Perfusion 2001;16:361-70.

Mehta 2007

Mehta RL, Kellum JA, Shah SV, Molitoris BA, Ronco C, Warnock DG, Levin A. Acute Kidney Injury Network: report of an initiative to improve outcomes in acute kidney injury. Critical Care 2007;11(2):R31. [DOI: 10.1186/ cc5713]

Morris 2001

Morris SJ. Leucocyte reduction in cardiovascular surgery. Perfusion 2001;16:371-80.

Nkomo 2006

Nkomo VT, Gardin JM, Skelton TN, Gottdiener JS, Scott CG, Enriquez-Sarano M. Burden of valvular heart diseases: a population based study. Lancet 2006;368:1005-11.

\section{Palanzo 1993}

Palanzo D, Manley N, Montesano R, Yeisley G, Gordon D. Clinical evaluation of the LeukoGuard (LG-6) arterial line filter for routine open-heart surgery. Perfusion 1993;8: 489-96.

\section{Papadopoulou 2009}

Papadopoulou EF, Mavrogeni SI, Dritsas A, Cokkinos DV. Assessment of quality of life using three activity questionnaires in heart failure patients after monthly, intermittent administration of levosimendan during a sixmonth period. Hellenic Journal of Cardiology 2009;50(4): 269-74.

\section{Pedersen 2010}

Pedersen SS, Versteeg H, Denollet J, Cheng JM, Serruys PW, van Domburg RT. Patient-rated health status predicts prognosis following percutaneous coronary intervention with drug-eluting stenting. Quality of Life Research 2011;20 (4):559-67.

\section{Sawa 1994}

Sawa Y, Matsuda H, Shimazaki Y, Kaneko M, Nishimura M, Amemiya A, et al.Evaluation of leucocyte-depleted 
terminal blood cardioplegic solution in patients undergoing elective and emergency coronary artery bypass grafting. The Journal of Thoracic and Cardiovascular Surgery 1994;108(6): 1125-31.

\section{Schueler 1992}

Schueler S, DeValeria PA, Hatanaka M, Cameron DE, Bando K, Zebley MA, et al.Successful twenty-four-hour lung preservation with donor core cooling and leucocyte depletion in an orthotopic double lung transplantation model. Journal of Thoracic and Cardiovascular Surgery 1992; 104(1):73-82.

\section{Soler-Soler 2000}

Soler-Soler J, Galve E. Worldwide perspective of valve disease. Heart 2000;83:721-5.

\section{Sutton 2005}

Sutton SW, Patel AN, Chase VA, Schmidt LA, Hunley EK, Yancey LW, et al.Clinical benefits of continuous leucocyte filtration during cardiopulmonary bypass in patients undergoing valvular repair or replacement. Perfusion 2005; 20:21-9.

\section{Taillefer 2005}

Taillefer MC, Dupuis G, Hardy JF, LeMay S. Quality of life before and after heart valve surgery is influenced by gender and type of valve. Quality of Life Research 2005;14 (3):769-78.

\section{Tang 2002}

Tang AT, Alexiou C, Hsu J, Sheppard SV, Haw MP, Ohri SK. Leukodepletion reduced renal injury in coronary revascularisation: a prospective randomised study. Annals of Thoracic Surgery 2002;74(2):372-7.

Thadhani 1996

Thadhani R, Pascual M, Bonventre JV. Acute renal failure. New England Journal of Medicine 1996;334(22):1448-60.

Thurlow 1996

Thurlow PJ, Doolan L, Sharp R, Sullivan M, Smith B, Andersen LW. Laboratory studies of the effect of Pall extracorporeal leucocyte filters LG6 and AV6 on patients undergoing coronary bypass grafts. Perfusion 1996;11(1): $29-37$.

\section{Vahanian 2007}

Vahanian A, Baumgartner H, Bax J, Butchart E, Dion R, Filippatos G, et al.Guidelines on the management of valvular heart disease. The Task Force on the Management of Valvular Heart Disease of the European Society of Cardiology. European Heart Journal 2007;28:230-68. [DOI: 10.1093/eurheartj/ehl428]

\section{Warren 2007a}

Warren O, Wallace S, Massey R, Tunnicliffe C, Alexiou $\mathrm{C}$, Powell J, et al.Does systemic leucocyte filtration affect perioperative hemorrhage in cardiac surgery? A systematic review and meta-analysis. ASAIO Journal 2007;53:514-21.

Warren 2007b

Warren O, Alexious C, Massey R, Leff D, Purkayastha $\mathrm{S}$, Kinross J, et al.The effects of various leucocyte filtration strategies in cardiac surgery. European Journal of Cardiothoracic Surgery 2007;31:665-76.

\section{Warren 2008}

Warren O, Tunnicliffe CR, Massey RM, Wallace S, Smith AJ, Alcock EMH, et al.Systemic leukofiltration does not attenuate pulmonary injury after cardiopulmonary bypass. ASAIO Journal 2008;54:78-88.

\section{Westaby 1987}

Westaby S. Organ dysfunction after cardiopulmonary bypass. A systemic inflammatory reaction initiated by the extracorporeal circuit. Intensive Care Medicine 1987;13: 89-95.

\section{Whitaker 2001}

Whitaker DC, Stygall JA, Newman SP, Harrison MJG. The use of leucocyte-depleting and conventional arterial line filters in cardiac surgery: a systematic review of clinical studies. Perfusion 2001;16:433-46.

* Indicates the major publication for the study 


\section{CHARACTERISTICS OF STUDIES}

\section{Characteristics of included studies [ordered by study ID]}

\section{Chen 2002}

\begin{tabular}{ll}
\hline Methods & Randomised controlled trial. Number of centres and blinding not stated \\
\hline Participants & 24 adult patients undergoing coronary artery bypass grafting (CABG), heart valve re- \\
& placement, or repair of a congenital heart defect randomised (leukodepletion filter (LD) \\
& 12 , control filter 12) \\
& Baseline characteristics: mean age 60 years, $88 \%$ male, 21 CABG, 2 valve replacement, \\
1 congenital heart defect & Inclusion: not stated \\
& Exclusion: infection, reoperation, emergency operation \\
\hline
\end{tabular}

Interventions

Same standard anaesthesia and CPB regimens used in both groups. Median sternotomy, 300 units/kg sodium heparin intravenously prior to CPB using a disposable membrane oxygenator. Moderate systemic hypothermia

Leukodepletion: Pall LG6 arterial line filter

Control: standard arterial line filter (no detail)

$\begin{array}{ll}\text { Outcomes } & \text { Intra-operative: CPB time } \\ \text { Total white blood cell count (WBC) } 10^{3} / \mathrm{mm}^{3} \text {, neutrophil counts of CD11a, CD11b, } \\ \text { CD11c and L-selectin } \\ \text { Blood samples collected from at } 7 \text { time points: } 1 \text {. after anaesthesia before sternotomy, 2- } \\ \begin{array}{l}\text { 4. After } 10,30,60 \text { minutes of CPB, } 5 \text {. conclusion of CPB, } 6.5 \text { mins after administration } \\ \text { of protamine, } 7.2 \text { hours after cessation of CPB }\end{array}\end{array}$

\begin{tabular}{l|l} 
Notes & First author emailed requesting outcome data for valve patients alone
\end{tabular}

Risk of bias

\begin{tabular}{l|l|l}
\hline Bias & Authors' judgement & Support for judgement \\
\hline $\begin{array}{l}\text { Random sequence generation (selection } \\
\text { bias) }\end{array}$ & Unclear risk & Not described \\
\hline Allocation concealment (selection bias) & Unclear risk & Not described \\
\hline $\begin{array}{l}\text { Incomplete outcome data (attrition bias) } \\
\text { All outcomes }\end{array}$ & Low risk & Data reported for all patients \\
\hline $\begin{array}{l}\text { Selective reporting (reporting bias) } \\
\begin{array}{l}\text { Blinding of participants and personnel } \\
\text { (performance bias) } \\
\text { All outcomes }\end{array}\end{array}$ & Unclear risk & All collected data reported \\
\hline
\end{tabular}

Leukodepletion for patients undergoing heart valve surgery (Review) 
Chen 2002 (Continued)

\begin{tabular}{l|l|l}
$\begin{array}{l}\text { Blinding of outcome assessment (detection } \\
\text { bias) }\end{array}$ & Unclear risk & Not described \\
All outcomes & & \\
\hline
\end{tabular}

\section{Chen 2004}

\begin{tabular}{ll} 
Methods & Randomised controlled trial. Number of centres and blinding not stated \\
\hline Participants & 32 consecutive adult patients undergoing coronary artery bypass grafting (CABG) or \\
& heart valve operation (leukodepletion filter (LD) 16, control filter 16) \\
& Baseline characteristics: mean age 61 years, $81 \%$ male, 31 CABG, 1 valve replacement \\
& Inclusion: not stated \\
& Exclusion: prior cardiac operation, infection, emergency operation, congestive heart \\
failure, acute myocardial infarction in past month, corticosteroid therapy, severe asthma, \\
COPD
\end{tabular}

Interventions

Identical anaesthetic and monitoring techniques were used in both groups. Median sternotomy, 300 units/kg sodium heparin intravenously prior to CPB using a disposable membrane oxygenator. Uncoated extracorporeal circuit. Moderate systemic hypothermia

Leukodepletion: Pall LG6 arterial line filter

Control: standard arterial line filter (no detail)

\begin{tabular}{l|l} 
Outcomes & $\begin{array}{l}\text { Intra-operative: CPB time } \\
\text { Total white blood cell count (WBC) } 10^{3} / \mathrm{mm}^{3} \text {, neutrophil count, plasma concentrations } \\
\text { of P-selectin, ICAM-1, IL-8, PECAM-1, oxygen index (before and after CPB), duration } \\
\text { of post-operative intubation and mediastinal drainage (cumulative after 24hrs in ICU) } \\
\text { Blood samples collected at } 7 \text { time points: } 1 . \text { after anaesthesia before sternotomy, } 2-3 . \\
\text { After } 30 \text { and } 60 \text { minutes of CPB, } 4 . \text { five minutes after coronary reperfusion, } 5 . \text { conclusion } \\
\text { of CPB, 6-7. two and } 24 \text { hours after cessation of CPB }\end{array}$ \\
\hline Notes & No valve patients in the control group
\end{tabular}

\section{Risk of bias}

\begin{tabular}{l|ll}
\hline Bias & Authors' judgement & Support for judgement \\
\hline $\begin{array}{l}\text { Random sequence generation (selection } \\
\text { bias) }\end{array}$ & Unclear risk & Not described \\
\hline Allocation concealment (selection bias) & Unclear risk & Not described \\
\hline $\begin{array}{l}\text { Incomplete outcome data (attrition bias) } \\
\text { All outcomes }\end{array}$ & Low risk & Data reported for all patients \\
\hline Selective reporting (reporting bias) & Low risk & All collected data reported
\end{tabular}




\begin{tabular}{l|l|l}
\hline $\begin{array}{l}\text { Blinding of participants and personnel } \\
\text { (performance bias) } \\
\text { All outcomes }\end{array}$ & Unclear risk & Not described \\
\hline $\begin{array}{l}\text { Blinding of outcome assessment (detection } \\
\text { bias) } \\
\text { All outcomes }\end{array}$ & Unclear risk & Not described \\
\hline
\end{tabular}

Efstathiou 2003a

Methods

Participants
Randomised controlled trial. Number of centres and blinding not stated

Sept 1999-Mar 200080 adult patients electively undergoing coronary artery bypass grafting $(\mathrm{CABG})$ or heart valve replacement or both (leukodepletion filter (LD) 40, control filter 40)

Baseline characteristics: mean age 61 years, $74 \%$ male, 65 CABG, 11 valve replacement, 3 both. $\mathrm{EF}<30 \% 5$ pts, EF 30-50\% 25 pts, EF $>50 \% 37$ pts

Inclusion: not stated

Exclusion: chronic renal failure, chronic pulmonary disease, malignancies and reoperation. Acetylsalicylic acid discontinued 8 days before operation

Interventions

Identical monitoring techniques were used in both groups. Median sternotomy, 300 units/kg sodium heparin prior to $\mathrm{CPB}$ using a membrane oxygenator primed with aprotinin. Moderate systemic hypothermia. After $\mathrm{CPB}$ all residual blood from the $\mathrm{CPB}$ machine was reinfused via the relevant arterial line filters in each group

Leukodepletion: Pall LG6 arterial line filter

Control: standard Pall arterial line filter

Outcomes

Intra-operative: $\mathrm{CPB}$ time

White blood cell count (WBC) $10^{9} / \mathrm{L}$ and platelet counts pre-operatively, 2, 18, 42 and 66 hours after $\mathrm{CPB}$, mean adrenaline dose in first 12 hours and catecholamine dose, oxygenation index every 2 hours for 14 hours, ventilation time (hours), ICU stay (hours), chest tube drainage $(\mathrm{ml} / 24 \mathrm{hrs})$, units packed red cells, urine output $(\mathrm{ml} / 24 \mathrm{hrs})$, hospital stay (days), number of pts with: wound infection, perioperative infarction, pulmonary atelectasis, arrhythmias, AF, VF or VT

Notes

First author emailed requesting outcome data for valve patients alone

\section{Risk of bias}

\begin{tabular}{l|ll}
\hline Bias & Authors' judgement & Support for judgement \\
\hline $\begin{array}{l}\text { Random sequence generation (selection } \\
\text { bias) }\end{array}$ & Unclear risk & Not described \\
\hline Allocation concealment (selection bias) & Unclear risk & Not described
\end{tabular}


Efstathiou 2003a (Continued)

\begin{tabular}{l|l|l}
\hline $\begin{array}{l}\text { Incomplete outcome data (attrition bias) } \\
\text { All outcomes }\end{array}$ & Unclear risk & Data reported for all patients \\
\hline Selective reporting (reporting bias) & Unclear risk & All collected data reported \\
\hline $\begin{array}{l}\text { Blinding of participants and personnel } \\
\text { (performance bias) }\end{array}$ & Unclear risk & Not described \\
\hline $\begin{array}{l}\text { All outcomes } \\
\text { Blinding of outcome assessment (detection } \\
\text { bias) }\end{array}$ & Unclear risk & Not described \\
\hline
\end{tabular}

\section{Hachida 1995}

\begin{tabular}{|c|c|}
\hline Methods & Randomised controlled trial. Number of centres and blinding not stated \\
\hline Participants & $\begin{array}{l}28 \text { adult patients undergoing open heart valvular surgery (leukodepletion filter (LD) } 14 \text {, } \\
\text { control filter 14) } \\
\text { Baseline characteristics: mean age } 54 \text { years, gender not stated, all valve surgery, no dif- } \\
\text { ference in pre-operative variables (body surface area, type of cardiac disease, haemoglobin } \\
\text { and neutrophil count). Mean pre-operative fractional shortening }<30 \% \text { in both groups } \\
\text { Inclusion: not stated } \\
\text { Exclusion: abnormal pre-operative lung function (pre-op arterial blood gases, chest x- } \\
\text { ray and pulmonary function) }\end{array}$ \\
\hline Interventions & $\begin{array}{l}\text { All patients on same CPB circuit (no detail) except for filter. Systemic cooling to } 28^{\circ} \mathrm{C} \\
\text { Leukodepletion: Pall LG6 arterial line filter after aortic declamp } \\
\text { Control: Pall Auto Vent-SV filter }\end{array}$ \\
\hline Outcomes & $\begin{array}{l}\text { Intra-operative: aortic cross-clamp time, CPB time } \\
\text { White blood cell count (WBC), CK-MB and lipid peroxide; pre-op, in first hour ( } 5 / \\
15 / 30 / 45 / 60 / \text { pump off (min), 3, 6, } 12 \text { and } 24 \text { hrs after reperfusion. Cardiac index } \\
\text { and percent fraction shortening pre- and post-op. Catecholamine dose after surgery. } \\
\text { Pulmonary index pre-op, } 3,6,12 \text { and } 24 \text { hours after reperfusion. Chest tube drainage, } \\
\text { blood product usage, post-operative chest x-rays. Post-operative infections }\end{array}$ \\
\hline Notes & \\
\hline
\end{tabular}

\section{Risk of bias}

\begin{tabular}{l|ll}
\hline Bias & Authors' judgement & Support for judgement \\
\hline $\begin{array}{l}\text { Random sequence generation (selection } \\
\text { bias) }\end{array}$ & Unclear risk & Not described \\
\hline Allocation concealment (selection bias) & Unclear risk & Not described
\end{tabular}


Hachida 1995 (Continued)

\begin{tabular}{l|l|l}
\hline $\begin{array}{l}\text { Incomplete outcome data (attrition bias) } \\
\text { All outcomes }\end{array}$ & Unclear risk & $\begin{array}{l}\text { Number of patients per outcome or with- } \\
\text { drawal and completion rates not reported }\end{array}$ \\
\hline $\begin{array}{l}\text { Selective reporting (reporting bias) } \\
\text { Blinding of participants and personnel } \\
\text { (performance bias) } \\
\text { All outcomes }\end{array}$ & Lnclear risk & All collected data reported \\
\hline $\begin{array}{l}\text { Blinding of outcome assessment (detection } \\
\text { bias) } \\
\text { All outcomes }\end{array}$ & Unclear risk & Not described \\
\hline
\end{tabular}

Hurst 1997

\begin{tabular}{|c|c|}
\hline Methods & Randomised controlled trial. Single centre, investigators blinded to intervention \\
\hline Participants & $\begin{array}{l}\text { July } 1993 \text {-Jun } 199424 \text { adult patients electively undergoing open heart valve surgery } \\
\text { (leukodepletion filter (LD) } 11 \text {, control filter } 13 \text { ) } \\
\text { Baseline characteristics: mean age } 62 \text { years, } 46 \% \text { male, all valve surgery. EF< } 50 \% 9 \\
\text { pts, } 13 \text { pts cough, } 11 \text { pts past smoker, } 22 \text { pts dyspnoea grade } 1-4 \\
\text { Inclusion: not stated } \\
\text { Exclusion: informed consent unobtainable, emergency surgery }\end{array}$ \\
\hline Interventions & $\begin{array}{l}\text { All patients followed to discharge. Surgery and anaesthesia according to usual practice } \\
\text { of } 2 \text { participating surgeons. Systemic cooling to } 24-28^{\circ} \mathrm{C} \text {. No CPB details } \\
\text { Leukodepletion: Pall LG6 arterial line filter } \\
\text { Control: Pall Autovent SP filter }\end{array}$ \\
\hline Outcomes & $\begin{array}{l}\text { Intra-operative: aortic cross-clamp time, CPB time, fluid balance, mediastinal blood loss } \\
\text { Haemodynamics and blood samples, pre-op, after anaesthetic induction, at aortic x- } \\
\text { clamp, 1/4/24 hrs post-op. systemic arterial pressure, right arterial pressure, pulmonary } \\
\text { artery pressure, pulmonary capillary wedge pressure, cardiac index, blood gases, oxy- } \\
\text { gen saturation, WBC count, neutrophil count, platelet count, IL-6SR, CD11b, CD18. } \\
\text { Weight, chest x-ray, fluid balance, FEV1 \& FVC on 2nd and 5th post-op day and dis- } \\
\text { charge. Echocardiography, fractional shortening, ejection fraction, wall motion abnor- } \\
\text { malities and atelectasis measured pre-op and on discharge. Number of MIs }\end{array}$ \\
\hline
\end{tabular}

Notes

Risk of bias

\begin{tabular}{|c|c|c|}
\hline Bias & Authors' judgement & Support for judgement \\
\hline $\begin{array}{l}\text { Random sequence generation (selection } \\
\text { bias) }\end{array}$ & Unclear risk & Not described \\
\hline Allocation concealment (selection bias) & Unclear risk & Not described \\
\hline
\end{tabular}




\section{Hurst 1997 (Continued)}

\begin{tabular}{l|ll}
\hline $\begin{array}{l}\text { Incomplete outcome data (attrition bias) } \\
\text { All outcomes }\end{array}$ & Unclear risk & $\begin{array}{l}\text { Number of patients per outcome or with- } \\
\text { drawal and completion rates not reported }\end{array}$ \\
\hline $\begin{array}{l}\text { Selective reporting (reporting bias) } \\
\text { Blinding of participants and personnel } \\
\begin{array}{l}\text { (performance bias) } \\
\text { All outcomes }\end{array}\end{array}$ & Low risk & All collected data reported \\
\hline $\begin{array}{l}\text { Blinding of outcome assessment (detection } \\
\text { bias) } \\
\text { All outcomes }\end{array}$ & Unclear risk & Investigators blinded to intervention \\
\hline
\end{tabular}

Leal-Noval 2005

Methods

Participants
Randomised controlled trial. Single centre. Stratified by risk (Parsonnet score)

June 2003-Dec 2003162 adult patients electively undergoing cardiac surgery (leukodepletion filter (LD) 54, control filter 108)

Baseline characteristics: mean age 61 years, 62\% male, 57 CABG, 94 valve surgery, 8 congenital defect. Mean Parsonnet score $6 \mathrm{EF}<50 \% 9$ pts

Inclusion: Low risk (Parsonnet score $\leq 10)$

Exclusion: urgent surgery, high risk (Parsonnet score $>10$ ), abnormal pre-operative pulmonary function (COPD, severe pulmonary hypertension), severe pre-operative cardiac dysfunction $(\mathrm{EF}<40 \%$, left main coronary artery disease, intra-aortic balloon pump prior to surgery), pre-operative anaemia (haemoglobin $<110 \mathrm{~g} / \mathrm{L}$ ), haemostatic dysfunction (platelet count $<200 \times 10^{9}$, thrombin or partial thromboplastin time $>1.5$ control), fever or infection symptoms before surgery

Interventions

Stratified into 3 groups by Parsonnet score (low<4, middle 4-7, high 8-10) then withinstrata 2:1 ratio randomisation into control or filter group. Perfusion and CPB using a disposable membrane oxygenator (primed with aprotinin for valve patients) were the same for all patients except for the arterial line filter. Filtration at start of CPB until end of procedure. Systemic cooling to $31^{\circ} \mathrm{C}$

Leukodepletion: Pall LG6 arterial line filter

Control: standard arterial line filter (no details)

Outcomes

Intra-operative: aortic cross-clamp time, CPB time

Morbidity using surrogate variables (length of stay in ICU, pulmonary function (intraop, after 1 and 4 hrs in ICU), cardiac function (perioperative ischemia, EF, cardiac output, post-op heart failure, cardiac enzymes (highest in $24 \mathrm{hrs}$ ), incidence of peri-operative infections (pneumonia, mediastinitis, sepsis), fever and hyperdynamic circulatory states. Leucocyte and platelet counts, and haemoglobin levels measured pre-op, aortic de-clamp, conclusion of $\mathrm{CPB}$, after 1 and $12 \mathrm{hrs}$ in ICU

Notes

Risk of bias

Leukodepletion for patients undergoing heart valve surgery (Review) 
Leal-Noval 2005 (Continued)

\begin{tabular}{l|l|l}
\hline Bias & Authors' judgement & Support for judgement \\
\hline $\begin{array}{l}\text { Random sequence generation (selection } \\
\text { bias) }\end{array}$ & Low risk & $\begin{array}{l}\text { 2:1 ratio block (block size not reported) } \\
\text { randomisation }\end{array}$ \\
\hline Allocation concealment (selection bias) & Low risk & $\begin{array}{l}\text { Sequentially numbered identical contain- } \\
\text { ers }\end{array}$ \\
\hline $\begin{array}{l}\text { Incomplete outcome data (attrition bias) } \\
\text { All outcomes }\end{array}$ & High risk & $\begin{array}{l}\text { 2 pts withdrew from LD group and 1 with- } \\
\text { drew from control group, reasons not re- } \\
\text { ported. All outcome data reported per pro- } \\
\text { tocol }\end{array}$ \\
\hline $\begin{array}{l}\text { Selective reporting (reporting bias) } \\
\begin{array}{l}\text { Blinding of participants and personnel } \\
\text { (performance bias) }\end{array}\end{array}$ & Unclear risk & All collected data reported \\
\hline $\begin{array}{l}\text { All outcomes } \\
\text { Blinding of outcome assessment (detection } \\
\text { All outcomes }\end{array}$ & Unclear risk & $\begin{array}{l}\text { Abstract states 'blind' study but not de- } \\
\text { scribed or mentioned in main text }\end{array}$ \\
\hline
\end{tabular}

Palanzo 1993a

\begin{tabular}{|c|c|}
\hline Methods & Randomised controlled trial. Number of centres and blinding not stated \\
\hline Participants & $\begin{array}{l}36 \text { adult patients electively undergoing open heart surgery for coronary artery disease or } \\
\text { aortic valvular disease (leukodepletion filter (LD) 18, control filter 18) } \\
\text { Baseline characteristics: mean age } 64 \text { years, gender not stated, number of valve patients } \\
\text { not stated } \\
\text { Inclusion: normal pre-operative lung function (pre-op arterial blood gases, chest x-rays, } \\
\text { pulmonary function) } \\
\text { Exclusion: abnormal pre-operative lung function (as above), EF not reported }\end{array}$ \\
\hline Interventions & $\begin{array}{l}\text { All patients on same CPB circuit (no detail) except for filter. Systemic cooling to } 28^{\circ} \mathrm{C} \\
\text { Leukodepletion: Pall LG6 arterial line filter } \\
\text { Control: Pall EC-Plus filter }\end{array}$ \\
\hline Outcomes & $\begin{array}{l}\text { Intra-operative: aortic cross-clamp time, } \mathrm{CPB} \text { time, urine output, blood and blood prod- } \\
\text { ucts used } \\
\text { White blood cell counts }\left(10^{3} / \mathrm{mm}^{3}\right) \text { including elastase concentrations }(\mu \mathrm{g} / \mathrm{L}) \text { measured } \\
\text { pre-op, immediately post-op, } 4 \text { and } 24 \text { hrs post-op, platelet measured as } \% \text { drop from } \\
\text { pre-op to immediately post-op and } 4 \mathrm{hrs} \text { post-op, haemoglobin }(\mathrm{g} / \mathrm{dl}) \text { measured pre-op, } \\
\text { post-bypass, immediately post-op, } 4 \text { and } 24 \text { hrs post-op, urine output }(\mathrm{L} / 24 \mathrm{hrs}) \text {, chest } \\
\text { tube drainage }(\mathrm{ml} / 24 \mathrm{hrs}) \text {, blood usage (units } / 1 \text { st } 24 \mathrm{hrs),} \mathrm{chest} \mathrm{x-rays,} \mathrm{arterial} \mathrm{blood} \mathrm{gases} \\
\text { (pCO } \mathrm{p}_{2} \text { and } \mathrm{pO}_{2}(\mathrm{mmHg}) \text { measured pre-op, post-bypass and post-extubation, ventilator } \\
\text { (hrs), ICU (hrs), systemic and pulmonary vascular resistance, } 1 \mathrm{st} 24 \mathrm{hr} \text { post-op body }\end{array}$ \\
\hline
\end{tabular}


Palanzo 1993a (Continued)

temperature

\begin{tabular}{ll}
\hline Notes & $\begin{array}{l}\text { First author emailed requesting outcome data for valve patients alone. Author replied } \\
\text { that data are no longer available }\end{array}$
\end{tabular}

Risk of bias

\begin{tabular}{l|ll}
\hline Bias & Authors' judgement & Support for judgement \\
\hline $\begin{array}{l}\text { Random sequence generation (selection } \\
\text { bias) }\end{array}$ & Unclear risk & Not described \\
\hline $\begin{array}{l}\text { Allocation concealment (selection bias) } \\
\text { Incomplete outcome data (attrition bias) }\end{array}$ & Unclear risk & Not described \\
\hline $\begin{array}{l}\text { All outcomes } \\
\text { Selective reporting (reporting bias) }\end{array}$ & Low risk & $\begin{array}{l}\text { Number of patients per outcome or with- } \\
\text { drawal and completion rates not reported }\end{array}$ \\
\hline $\begin{array}{l}\text { Blinding of participants and personnel } \\
\text { (performance bias) }\end{array}$ & Unclear risk & All collected data reported \\
\hline $\begin{array}{l}\text { All outcomes } \\
\text { Blinding of outcome assessment (detection } \\
\text { All outcomes }\end{array}$ & Unclear risk & Not described \\
\hline
\end{tabular}

\section{Soo 2010}

Methods

Participants
Randomised controlled trial. Single centre. Blinded investigators

40 adult patients undergoing elective CABG or valvular heart surgery (leukodepletion filter (LD) 20, control filter 20)

Baseline characteristics: mean age 62 years, 73\% male, 18 CABG, 19 valve, 3 both, EF good/moderate/poor (no definition)

Inclusion: not stated

Exclusion: active infection, emergency operation, pre-operative corticosteroid therapy, severe asthma or COPD

Interventions

Similar anaesthetic and monitoring techniques were used in both groups. Median sternotomy, 300 units $/ \mathrm{kg}$ sodium heparin intravenously prior to $\mathrm{CPB}$ using a membrane oxygenator primed with crystalloid solution. Mild hypothermia, $32^{\circ} \mathrm{C}$

Leukodepletion: Pall LG6 arterial line filter

Control: standard arterial line filter (no detail)

Outcomes

Intra-operative: $\mathrm{CPB}$ time, aortic cross-clamp time

Bloods measured pre-op (within 12 hrs of op), 5 mins after x-clamp release. Total white blood cell count (WBC) $\left(x 10^{9}\right)$, \% neutrophil $\left(x 10^{9}\right)$, neutrophil surface adhe- 
sion molecule expression: CD11b, CD62L, PSGL-1. Time to extubation (hrs), duration of postoperative ventilation (hrs), respiratory index $\left(\mathrm{PaO}_{2} / \mathrm{FiO}_{2}\right)$ before extubation $(\mathrm{mmHg})$, total mediastinal chest drainage $(\mathrm{ml})$ cumulatively after $24 \mathrm{hrs}$ in ICU, cardiac function (CKMB-fraction (after $24 \mathrm{hrs}$ in ICU), amount and duration of inotropic support (hrs), cumulative adrenaline usage $(\mu \mathrm{g} / \mathrm{kg} / \mathrm{hr})$, duration of adrenaline usage (hrs), cumulative noradrenaline usage ( $\mu \mathrm{g} / \mathrm{kg} / \mathrm{hr}$ ), duration of noradrenaline usage (hrs), highest lactate level (median), max change in serum creatinine (ratio of max post-op to preop), ICU stay (hrs)

\section{Notes}

\section{Risk of bias}

\begin{tabular}{|c|c|c|}
\hline Bias & Authors' judgement & Support for judgement \\
\hline $\begin{array}{l}\text { Random sequence generation (selection } \\
\text { bias) }\end{array}$ & Unclear risk & Not described \\
\hline Allocation concealment (selection bias) & Low risk & $\begin{array}{l}\text { Randomisation was achieved with sealed } \\
\text { envelopes given to the perfusion depart- } \\
\text { ment }\end{array}$ \\
\hline $\begin{array}{l}\text { Incomplete outcome data (attrition bias) } \\
\text { All outcomes }\end{array}$ & Low risk & $\begin{array}{l}\text { Complete patient numbers reported for all } \\
\text { outcomes indicate no study withdrawal }\end{array}$ \\
\hline Selective reporting (reporting bias) & Low risk & All collected data reported \\
\hline $\begin{array}{l}\text { Blinding of participants and personnel } \\
\text { (performance bias) } \\
\text { All outcomes }\end{array}$ & Low risk & $\begin{array}{l}\text { A record of the filter used for each patient } \\
\text { was kept by the perfusion staff. This record } \\
\text { was revealed only during data analysis. All } \\
\text { other investigators were blinded to the pa- } \\
\text { tient allocation }\end{array}$ \\
\hline $\begin{array}{l}\text { Blinding of outcome assessment (detection } \\
\text { bias) } \\
\text { All outcomes }\end{array}$ & Unclear risk & Not described \\
\hline
\end{tabular}

Characteristics of excluded studies [ordered by study ID]

\begin{tabular}{l|l}
\hline Study & Reason for exclusion \\
\hline Bilgin 2002 & Did not meet inclusion criteria. Blood transfusion, no filter on arterial line of cardiopulmonary bypass \\
\hline Dell'Amore 2010 & Not an arterial line filter. Residual blood \\
\hline El-Tahan 2009 & Did not meet inclusion criteria. Ultrafiltration, no filter on arterial line of cardiopulmonary bypass \\
\hline $\begin{array}{l}\text { Leukodepletion for patients undergoing heart valve surgery (Review) } \\
\text { Copyright @ } 2013 \text { The Cochrane Collaboration. Published by John Wiley \& Sons, Ltd. }\end{array}$
\end{tabular}


(Continued)

\begin{tabular}{|c|c|}
\hline Gott 1998 & $\begin{array}{l}\text { Did not meet inclusion criteria. Not solely arterial line leukodepletion; also leukodepleted cardioplegia, } \\
\text { salvaged and post-operative blood products }\end{array}$ \\
\hline Gu 1999a & Did not meet inclusion criteria. Filter on venous line of cardiopulmonary bypass \\
\hline Hamada 2001 & Did not meet inclusion criteria. Patients for coronary artery bypass graft \\
\hline Johnson 1995 & Did not meet inclusion criteria. Patients for coronary artery bypass graft \\
\hline Karaiskos 2004 & Not an RCT and did not meet exclusion criteria: mean ejection fraction; filter $=27 \%$, control $=31 \%$ \\
\hline Komai 1998 & Did not meet inclusion criteria. Patients for ventricular septal defect \\
\hline Lust 1996 & Did not meet exclusion criteria. Patients for coronary artery bypass graft \\
\hline Matheis $2001 b$ & Did not meet inclusion criteria. Patients for coronary artery bypass graft \\
\hline Onorati 2011 & Did not meet inclusion criteria. Not solely arterial line leukodepletion; also leukodepleted cardioplegia \\
\hline Pala 1995 & Did not meet inclusion criteria. Leukodepletion on cardioplegia circuit only \\
\hline Scholz 2002 & Did not meet inclusion criteria. Patients for coronary artery bypass graft \\
\hline Smit 1999 & Did not meet inclusion criteria. Filter on venous line of cardiopulmonary bypass \\
\hline Soo 2008 & Did not meet inclusion criteria. In vitro study (see Soo 2010) \\
\hline Soo 2009 & Did not meet inclusion criteria. In vitro study (see Soo 2010) \\
\hline van de Watering 1996 & Did not meet inclusion criteria. Blood transfusion, no filter on arterial line of cardiopulmonary bypass \\
\hline Zhang 2005 & Did not meet inclusion criteria. No leukocyte depletion filter \\
\hline
\end{tabular}

Characteristics of studies awaiting assessment [ordered by study ID]

Allen 1994

\begin{tabular}{ll}
\hline Methods & RCT \\
\hline Participants & 50 patients (26 LD, 24 standard filter). No detail on age, specific surgery or gender \\
\hline Interventions & $\begin{array}{l}\text { Anaesthesia, operation and CPB standardised. Pall LG6 arterial line filter versus Pall EC Plus arterial line filter. } \\
\text { Systemic hypothermia to } 28^{\circ} \mathrm{C}\end{array}$
\end{tabular}




\section{Allen 1994 (Continued)}

\begin{tabular}{ll} 
Outcomes & $\begin{array}{l}\text { Total and differential white blood cell counts measured } 8 \text { times from before start of CPB to } 24 \text { hours after CPB (pre- } \\
\text { op, start } \mathrm{CPB}, 15 \mathrm{mins} \text { into } \mathrm{CPB}, 30 \mathrm{mins} \text { into } \mathrm{CPB}, 5 \text { mins after cross-clamp removal, } \mathrm{CPB}+5 \mathrm{mins}, \mathrm{CPB}+30 \mathrm{mins}, \\
\mathrm{CPB}+120 \mathrm{mins}, 24 \text { hours after end of } \mathrm{CPB}) \text { Pulmonary function: alveolar arterial oxygen gradients, compliance, } \\
\text { clinical morbidity scale }\end{array}$ \\
\hline Notes & Conference abstract. Unclear whether valve patients. First author emailed for further information \\
\hline
\end{tabular}

de Vries 2003

\begin{tabular}{|c|c|}
\hline Methods & RCT \\
\hline Participants & 40 adult patients ( 25 male), aged 65 , undergoing CABG or valve surgery ( 7 relevant valve) \\
\hline Interventions & $\begin{array}{l}\text { Grp 1: Pall LG6 arterial line filter, Grp 2: Pall RS1 paired leucocyte removal filters on venous return during rewarming, } \\
\text { Grp3: Pall RS1 leucofiltration of residual heart-lung machine blood at transfusion after CPB, Grp4: No leucofiltration } \\
\text { controls }\end{array}$ \\
\hline Outcomes & $\begin{array}{l}\text { Blood cell counts, arterial oxygen tension and alveolar-arterial oxygen gradient, plasma elastase, perioperative fluid } \\
\text { balance, use of inotropic agents, myocardial infarctions, duration of postoperative intubation, length of stay in ICU } \\
\text { and hospital }\end{array}$ \\
\hline Notes & $\begin{array}{l}\text { Unclear whether control group included standard arterial line filters as authors state "Arterial line filters other than the } \\
\text { one studied were not used". First author emailed for clarification }\end{array}$ \\
\hline
\end{tabular}

\section{Koskenkari 2006}

\begin{tabular}{ll} 
Methods & RCT \\
\hline Participants & $\begin{array}{l}20 \text { adults patients (17 male), aged } 70 \text { years, undergoing valve replacement with coronary revascularisation. 10 LD } \\
\text { and } 10 \text { control group }\end{array}$ \\
\hline Interventions & Pall LG6 arterial line filter versus control group. Moderate systemic hypothermia $34^{\circ} \mathrm{C}$ \\
\hline Outcomes & $\begin{array}{l}\text { ICU stay, surgical ward stay, intubation time, arterial saturation, blood transfusion, platelet transfusion, inotropic } \\
\text { and vasopressor support, myocardial infarction, blood cell counts, cytokine analysis }\end{array}$ \\
\hline Notes & $\begin{array}{l}\text { Unclear whether control group included standard arterial line filter as authors state LG6 used in intervention group } \\
\text { but CPB in control conducted "without such a filter". Sixth author emailed for further information }\end{array}$
\end{tabular}

\section{Ohto 2000}

Methods Unclear. "Twenty-six adults operated for valvular heart disease were included in this study"

Participants 26 adults (12 male), aged 56, undergoing valve surgery. 13 LD and 13 control

Interventions Pall LG6 arterial line leucodepletion filter verus Pall Auto Vent-SV standard arterial line filter 
Ohto 2000 (Continued)

Outcomes Blood cell counts, elastase and lipoperoxide concentrations and oxygenation index, blood transfusions

Notes Unclear whether patients were randomised to the two arms. Second author emailed for further information

Zhang 2010

\begin{tabular}{ll}
\hline Methods & RCT \\
\hline Participants & 52 adult patients (20 male) aged 43 years, undergoing valve surgery. 26 LD and 26 standard filter \\
\hline Interventions & Pall LG6 arterial line filter versus control group. Moderate systemic hypothermia $25-28^{\circ} \mathrm{C}$ \\
\hline Outcomes & $\begin{array}{l}\text { Blood cell counts, creatinine kinase, troponin I, oxygen index, inotropic support, duration of mechanical ventilation, } \\
\text { length of ICU stay and length of hospital stay }\end{array}$ \\
\hline Notes & $\begin{array}{l}\text { Unclear whether control group included standard arterial line filter as authors state that the control group "received } \\
\text { the same CPB circuit as the filter group but without the leucocyte filter." Last author emailed for further information }\end{array}$ \\
\hline
\end{tabular}


DATA ANDANALYSES

Comparison 1. Leukodepletion versus standard filter

\begin{tabular}{lcccc} 
Outcome or subgroup title & $\begin{array}{c}\text { No. of } \\
\text { studies }\end{array}$ & $\begin{array}{c}\text { No. of } \\
\text { participants }\end{array}$ & Statistical method & Effect size \\
\hline 1 Length of hospital stay & 1 & 24 & Mean Difference (IV, Fixed, 95\% CI) & $0.20[-1.78,2.18]$ \\
2 Length of stay ICU & 1 & 24 & Mean Difference (IV, Fixed, 95\% CI) & $0.8[-0.24,1.84]$ \\
\hline
\end{tabular}

\section{CONTRIBUTIONS OFAUTHORS}

Sally Spencer - designing the methods and search strategy, extracting data, assessing study quality, analysing the data and drafting the review

Augustine Tang - proposing the review title, drafting the methods, supporting the searches, editing the review

Espeed Khoshbin - developing the methods, evaluating the searches, extracting study information and data, and drafting the review

\section{DECLARATIONSOF INTEREST}

Mr Tang was the chief investigator in a study of leukodepletion in cardiac surgery (Tang 2002) funded by the Royal College of Surgeons of Edinburgh.

Dr Spencer and Mr Khoshbin are co-investigators on a forthcoming RCT, led by Mr Tang, investigating the renoprotective benefits of leukodepletion for valve surgery patients.

\section{SOURCES OF SUPPORT}

\section{Internal sources}

- No funding was received for the development of this review., Not specified.

\section{External sources}

- No funding was received for the development of this review., Not specified. 


\section{DIFFERENCES BETWEEN PROTOCOLANDREVIEW}

None

\section{NDEX TERMS}

\section{Medical Subject Headings (MeSH)}

Cardiopulmonary Bypass [adverse effects; mortality]; Heart Valves [* surgery]; Length of Stay; Leukocyte Reduction Procedures [*methods]; Randomized Controlled Trials as Topic [instrumentation]

\section{MeSH check words}

Humans 